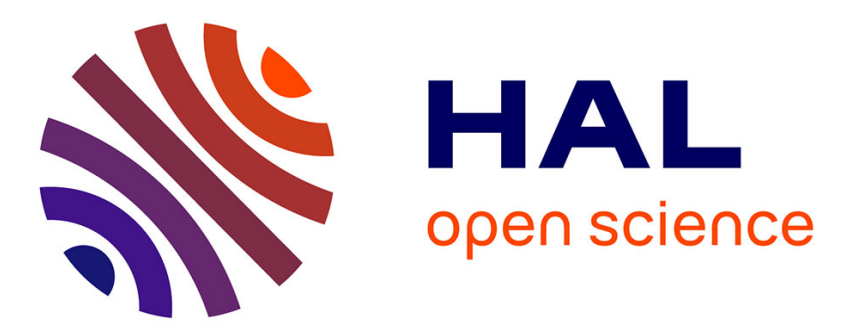

\title{
Late Quaternary variability of sedimentary nitrogen isotopes in the eastern South Pacific Ocean
}

R. de Pol-Holz, O. Ulloa, F. Lamy, Laurent Dezileau, Pierre Sabatier, D. Hebbeln

\section{- To cite this version:}

R. de Pol-Holz, O. Ulloa, F. Lamy, Laurent Dezileau, Pierre Sabatier, et al.. Late Quaternary variability of sedimentary nitrogen isotopes in the eastern South Pacific Ocean. Paleoceanography, 2007, 22 (2), pp.PA2207. 10.1029/2006PA001308 . hal-00407260

\section{HAL Id: hal-00407260 \\ https://hal.science/hal-00407260}

Submitted on 22 Mar 2021

HAL is a multi-disciplinary open access archive for the deposit and dissemination of scientific research documents, whether they are published or not. The documents may come from teaching and research institutions in France or abroad, or from public or private research centers.
L'archive ouverte pluridisciplinaire HAL, est destinée au dépôt et à la diffusion de documents scientifiques de niveau recherche, publiés ou non, émanant des établissements d'enseignement et de recherche français ou étrangers, des laboratoires publics ou privés. 


\title{
Late Quaternary variability of sedimentary nitrogen isotopes in the eastern South Pacific Ocean
}

\author{
Ricardo De Pol-Holz, ${ }^{1,2}$ Osvaldo Ulloa, ${ }^{3,4}$ Frank Lamy, ${ }^{5,6}$ Laurent Dezileau, ${ }^{7}$
} Pierre Sabatier, ${ }^{7}$ and Dierk Hebbeln ${ }^{8,9}$

Received 25 April 2006; revised 8 September 2006; accepted 1 December 2006; published 1 May 2007.

[1] We present high-resolution bulk sedimentary $\delta^{15} \mathrm{~N}$ data from the southern edge of the present-day oxygen minimum zone of the eastern South Pacific. The record is interpreted as representing changes in water column nitrogen removal during the last 70,000 years. We found significant fluctuations in the isotopic signal that suggest major reorganizations of the oxygen minimum zone at millennial timescales. These fluctuations were not related to other millennial-scale changes like the Northern Hemisphere's Dansgaard-Oeschger climate swings or local changes in primary productivity, so appear to be dictated by the Southern Hemisphere's climate rhythm. This is preliminarily corroborated by an overall agreement between our $\delta^{15} \mathrm{~N}$ data and the sedimentary proxy of ice sheet dynamics in Patagonia, which is in turn correlated with surface water properties at the midlatitude subduction region of the eastern South Pacific intermediate waters. Finally, potential implications on late Quaternary changes in atmospheric $\mathrm{CO}_{2}$ concentrations are discussed.

Citation: De Pol-Holz, R., O. Ulloa, F. Lamy, L. Dezileau, P. Sabatier, and D. Hebbeln (2007), Late Quaternary variability of sedimentary nitrogen isotopes in the eastern South Pacific Ocean, Paleoceanography, 22, PA2207, doi:10.1029/2006PA001308.

\section{Introduction}

[2] The oxygen minimum zone (OMZ) in the water columns of the Arabian Sea (AS) and the eastern North and South Pacific oceans (ENP; ESP) holds microbial communities that remove reactive or fixed nitrogen (mainly in the form of $\mathrm{NO}_{3}^{-}$) from the marine ecosystem. The nitrogen removal (NR) that takes place in these OMZs has the potential of affecting the climate in an indirect fashion, since it partially modulates the total amount of nitrogen available for phytoplankton growth and hence the efficiency of the oceanic carbon sequestration, and directly by the production of the greenhouse gas $\mathrm{N}_{2} \mathrm{O}$. Two decades ago, the estimated global rates of NR were in the order of $100 \mathrm{Tg} \mathrm{N} \mathrm{yr}^{-1}$ [Codispoti and Christensen, 1985], with a mean residence time for $\mathrm{NO}_{3}^{-}$in the ocean of about $10^{4}$ years [ $\left.\mathrm{Liu}, 1979\right]$. This timescale suggested a close link between changes in NR rates and the glacial-interglacial variations in atmospheric $\mathrm{CO}_{2}[$ McElroy, 1983]. The present

\footnotetext{
${ }^{1}$ Programa de Doctorado en Oceanografía, Unversidad de Concepción, Concepción, Chile.

${ }^{2}$ Now at Department of Geology and Geophysics, Woods Hole Oceanographic Institution, Woods Hole, Massachusetts, USA.

${ }^{3}$ Departamento de Oceanografía, Universidad de Concepción, Concepción, Chile.

${ }^{4}$ Also at Center for Oceanographic Research in the eastern South Pacific, Concepción, Chile.

${ }^{5}$ GeoForschungsZentrum-Potsdam, Telegrafenberg, Potsdam, Germany.

${ }^{6}$ Now at Alfred Wegener Institut, Bremerhaven, Germany.

${ }^{7}$ Géosciences Montpellier, Université Montpellier 2, Montpellier, France.

${ }^{8}$ Fachbereich Geowissenschaften, Universität Bremen, Bremen, Germany.

${ }^{9}$ Also at Research Center Ocean Margins, Bremen, Germany.
}

Copyright 2007 by the American Geophysical Union. 0883-8305/07/2006PA001308\$12.00 understanding, however, points to a much more dynamic oceanic $\mathrm{N}$ cycle, with modern $\mathrm{NR}$ rates estimated in the order of 200-400 Tg N yr ${ }^{-1}$ and a mean $\mathrm{NO}_{3}^{-}$residence time in the order of only 1500-3000 years [Brandes and Devol, 2002; Codispoti, 1995; Codispoti et al., 2001]. Therefore millennial-scale variations in the intensity of the NR in the OMZs during the last ice age, like those recorded in the nitrogen isotopic composition in the sediment's organic matter of the AS [Altabet et al., 2002; Suthhof et al., 2001] and the ENP [Behl and Kennett, 1996; Emmer and Thunell, 2000; Thunell and Kepple, 2004], become of interest for climate studies, since they could lead to significant changes in the total amount of reactive nitrogen in the ocean, with potential consequences for the suborbital variability of global primary productivity and the sequestration of $\mathrm{CO}_{2}$ in the atmosphere [Altabet et al., 2002].

[3] Unlike the broad, orbital-tuned changes in NR that were common to all OMZs at glacial-interglacial timescales [Ganeshram et al., 2000], the shorter millennial-scale variations in NR should reflect the microbiological response to more localized climate forcing, such as regional changes in primary productivity and/or ocean circulation. Therefore millennial-scale variations in NR are expected to show relatively marked differences between basins. Remarkably, the OMZ intensity and NR in the Northern Hemisphere (NH), both in the AS and the ENP, varied synchronously with the millennial-scale Dansgaard/Oeschger abrupt climate shifts that punctuated the $\mathrm{NH}$ during the last glacial epoch. This synchronicity was most likely the result of a common NH's climate modulation of local biological productivity and/or local intermediate water ventilation in this two distant areas [Altabet et al., 2002; Behl and Kennett, 1996; Cannariato and Kennett, 1999; Emmer and Thunell, 2000; Hendy et al., 2004; Suthhof et al., 2001]. The effect 


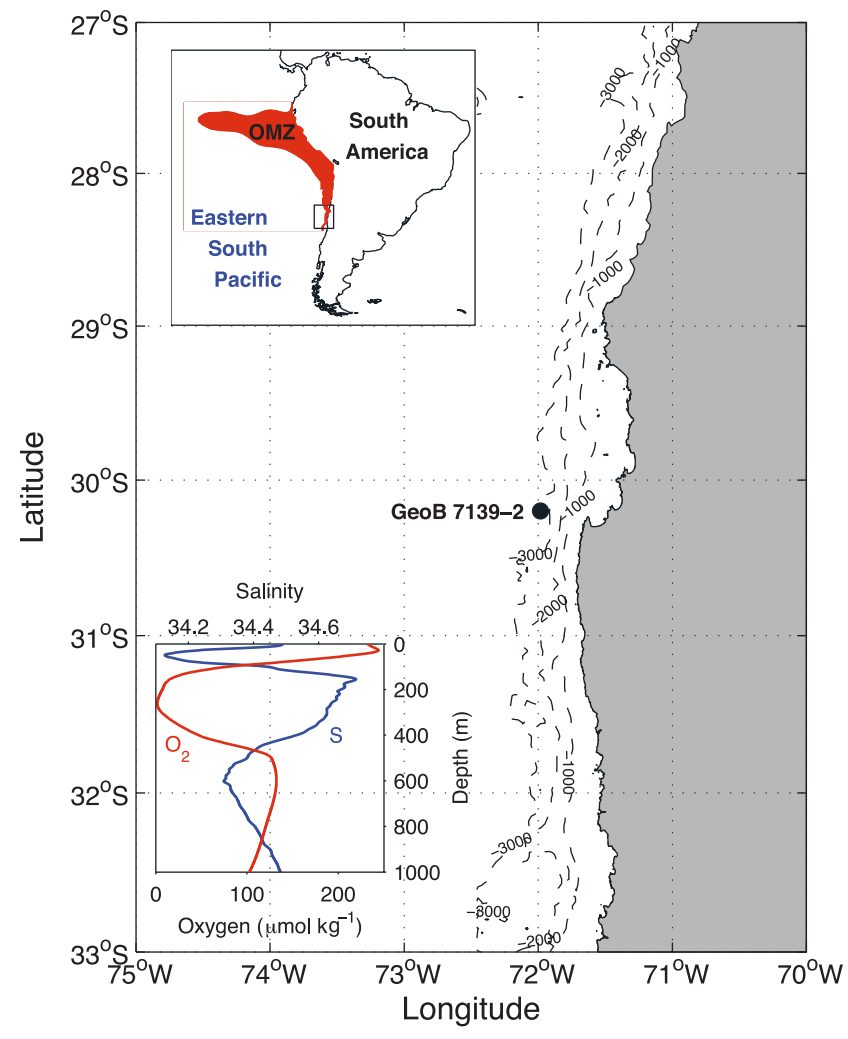

Figure 1. Map of central to northern Chile and the adjacent eastern South Pacific showing the location of the sediment core GeoB 7139-2 (30¹2.00'S; 7158.99'W; $3267 \mathrm{~m}$ water depth). Dashed lines represent the 1000, 2000 , and $3000 \mathrm{~m}$ isobaths. The core site lies at the southern boundary of the region where $\mathrm{O}_{2}$ levels drop below $20 \mu \mathrm{M}$ as an annual mean (red shaded area in the upper inset). The lower inset shows salinity (solid blue line) and oxygen (solid red line) distributions as a function of water depth at the core site. Note the oxygen-depleted waters (oxygen minimum zone (OMZ)) between 150 and $350 \mathrm{~m}$ and the salinity minimum at $\sim 100 \mathrm{~m}$.

on global nitrate inventories and greenhouse gas emissions has been highlighted by previous studies, showing that warm interstadial climates were characterized by increased NR rates and therefore probably promoted a weaker biological pump and enhanced nitrous oxide emissions and the opposite during cold stadials [Altabet et al., 2002; Suthhof et al., 2001].

[4] For the Southern Hemisphere (SH) however, there are no comparable high-resolution nitrogen isotope studies focusing on the millennial-scale NR changes during the last glacial period. This is a serious limitation to our understanding of the past nitrogen cycle and its potential role in forcing millennial-scale $\mathrm{CO}_{2}$ changes in the atmosphere. This limitation rises from the fact that the NR forcing on atmospheric $\mathrm{CO}_{2}$ changes is a function of the global NR history and not of the NR occurring in one hemisphere only. In addition, we expect that the interhemispheric difference in NR could be particularly critical at the millennial time- scale, since our present understanding points to a climate asynchrony between both hemispheres during abrupt millennial-scale climate changes [Blunier and Brook, 2001; Stocker, 1998].

[5] On the one hand, the NR in the SH could have been paced by southern, high-latitude climate dynamics, potentially showing "Antarctic type" millennial-scale patterns, as those observed in late Quaternary sea surface temperature [Kaiser et al., 2005; Lamy et al., 2004], and deglacial nitrogen isotope records from the ESP [De Pol-Holz et al., 2006; Higginson and Altabet, 2004]. On the other hand, because of its geographic location, the water column NR in the $\mathrm{SH}$ could have varied according to low-latitude millennial-scale climate dynamics, especially to those related with El Niño Southern Oscillation (ENSO)-like configurations in the Equatorial Pacific that appear to be an important mode of NR variability in the modern Pacific realm [Altabet et al., 1999; Codispoti et al., 1988; Codispoti et al., 1986; Morales et al., 1999]. According to recent results based on proxies from the eastern and western sides of the Equatorial Pacific, at millennial timescales, the ENSO-like system resembled Dansgaard-Oeschger or "Greenland type" variability [Koutavas et al., 2002; Stott et al., 2002; Turney et al., 2004]. Thus we have a complex system that can be potentially influenced by various remoteforcing mechanisms, but at the same time, each of them with a distinct type of $\mathrm{NH}$ or $\mathrm{SH}$ rhythm. Finally, it might also be possible that the NR in the ESP did not respond to remotely forced mechanisms but rather to local processes, such as the oxygen consumption generated by changes in upwelling and its associated biological production [Ganeshram et al., 2000].

[6] Here we present the first high-resolution sedimentary nitrogen isotopes from the southern edge of the OMZ in the ESP that extends to well within the last ice age. Part of this record was the subject of a previous work that discussed in detail the Glacial-Holocene transition of the NR process in the ESP [De Pol-Holz et al., 2006]. Here we extend the record back to $70 \mathrm{ka} \mathrm{B}$. P. and discuss the link between the sedimentary nitrogen-isotope composition and the intensity of the NR in the OMZ. We then try to assess the most probable mechanisms behind the observed variability and the implications for the hypothesis of a global, millennialscale, water column NR forcing on atmospheric $\mathrm{CO}_{2}$.

\section{Study Area and Modern Oceanographic Setting}

[7] Our study is based on analyses performed on sediment core GeoB 7139-2, which was recovered from the lower continental margin off northern Chile $\left(30^{\circ} 12^{\prime} \mathrm{S}, 71^{\circ} 59^{\prime} \mathrm{W}\right.$; $8.41 \mathrm{~m}$ long; $3269 \mathrm{~m}$ water depth) during the PUCK expedition onboard the German R/V Sonne in 2001 [Hebbeln et al., 2001] (Figure 1). The core location lies in the realm of the Chile-Peru current system, which extends for almost $40^{\circ}$ of latitude as the northward eastern branch of the ESP subtropical gyre. The Chile-Peru current system communicates the surface properties of the northern margin of the Antarctic circumpolar current to lower latitudes. The atmospheric forcing of the current system is characterized 

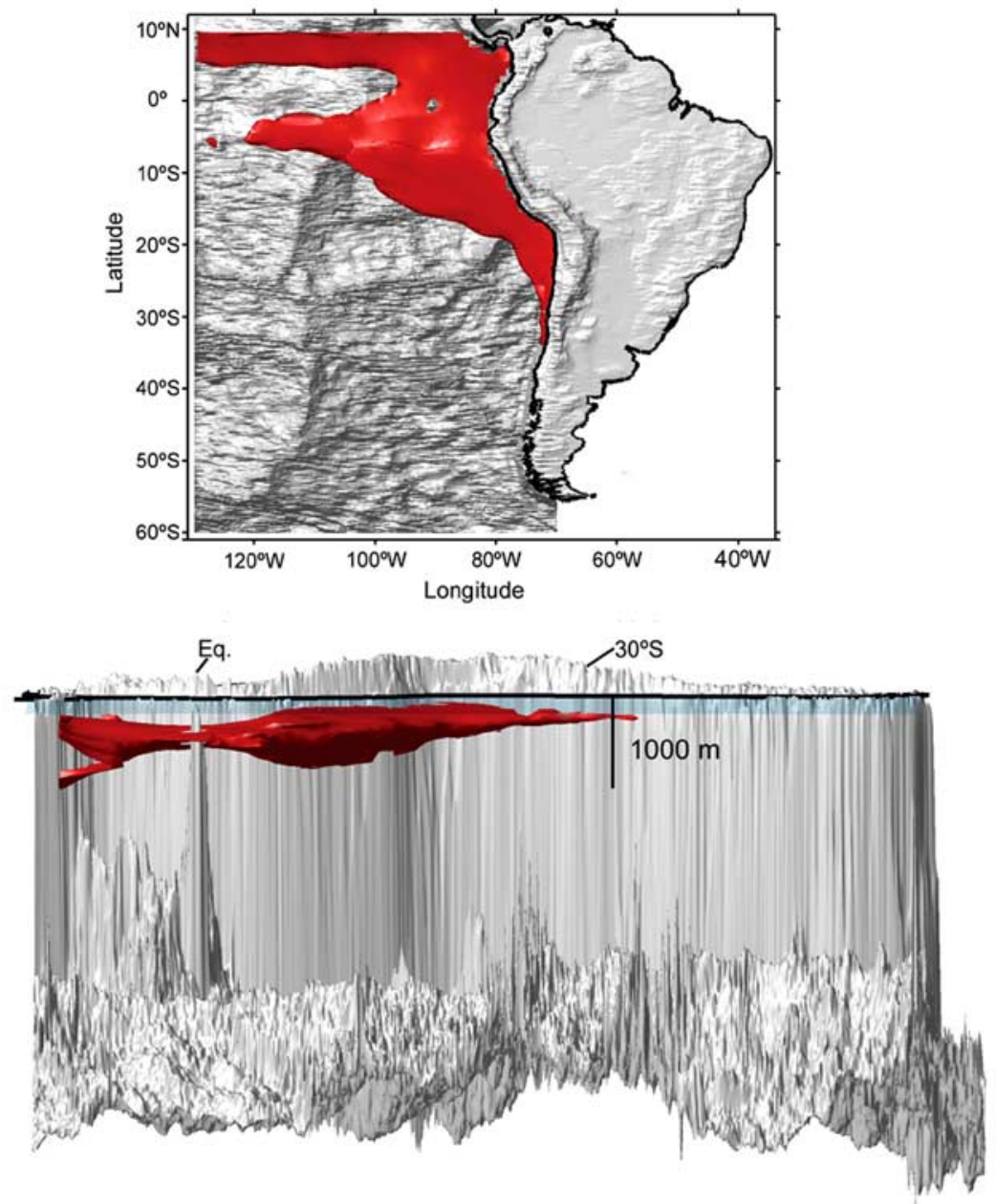

Figure 2. Three-dimensional view of the present-day eastern South Pacific oxygen minimum zone generated using the World Ocean Atlas 1994 climatology data (http://www.cdc.noaa.gov/cdc/ data.nodc.woa94.html). The red shading encloses the oceanic volume with oxygen contents below $0.5 \mathrm{ml} \mathrm{L}{ }^{-1}(\sim 23 \mu \mathrm{mol} / \mathrm{kg})$. A smoothed topography is also shown (ETOPO 5). Above-sea-level topography was reduced by a factor of 10 for clarity. The data were downloaded from http:// ingrid.ldeo.columbia.edu/SOURCES.

by southeasterly winds that promote upwelling and high biological productivity near the coast. The coastal upwelling is driven by the offshore Ekman transport that brings nutrient-rich waters near the surface. The upwelling is a quasi-perennial feature at $30^{\circ} \mathrm{S}$, but it can be strongly affected by the El Niño Southern Oscillation (ENSO) [Hormazábal et al., 2001]. Therefore as two of the main constituents of the variability of the Chile-Peru current system are the ACC and ENSO, the core location has the potential to respond to tropical and/or high-latitude forcing [Mohtadi and Hebbeln, 2004].

[8] The surface ocean off Chile around $30^{\circ} \mathrm{S}$ is occupied by the relatively salty subtropical surface waters (STSW) that characterize the surface of the ESP north of the subtropical front [Tsuchiya and Talley, 1998]. The OMZ (defined here as the volume where the total dissolved oxygen concentration is lower than $0.5 \mathrm{ml} \mathrm{L}^{-1}$ or $\sim 23 \mu \mathrm{mol} \mathrm{kg}^{-1}$ ) is a permanent feature in the present-day study area. Figure 2 shows that the OMZ in the ESP is a large volume of water extending horizontally from the Equator to the extratropical latitude of $\sim 33^{\circ} \mathrm{S}$ and from the South American coast to $120^{\circ} \mathrm{W}$ offshore near $5^{\circ} \mathrm{S}$, where it is widest. In the vertical, the OMZ occupies the subsurface layer from $\sim 50 \mathrm{~m}$ to $1000 \mathrm{~m}$ where it is deepest between $5^{\circ} \mathrm{S}$ and $10^{\circ} \mathrm{S}$. Farther to the south, the $\mathrm{OMZ}$ is much narrower in the zonal direction and thinner. Off Chile, the $\mathrm{OMZ}$ reaches about $\sim 400-500 \mathrm{~m}$ depth and the upper boundary frequently intercepts the photic zone during upwelling. Oxygen concentrations drop sharply in the uppermost $100 \mathrm{~m}$ of the water column where there is also a distinct salinity gradient (Figure 1). This gradient represents the transition from relatively fresh and recently subducted subantarctic surface waters (SASW) - in the form of eastern South Pacific intermediate water (ESPIW) - to saltier equatorial subsurface waters (ESSW), characterized by higher nutrients and lower oxygen concentrations derived 

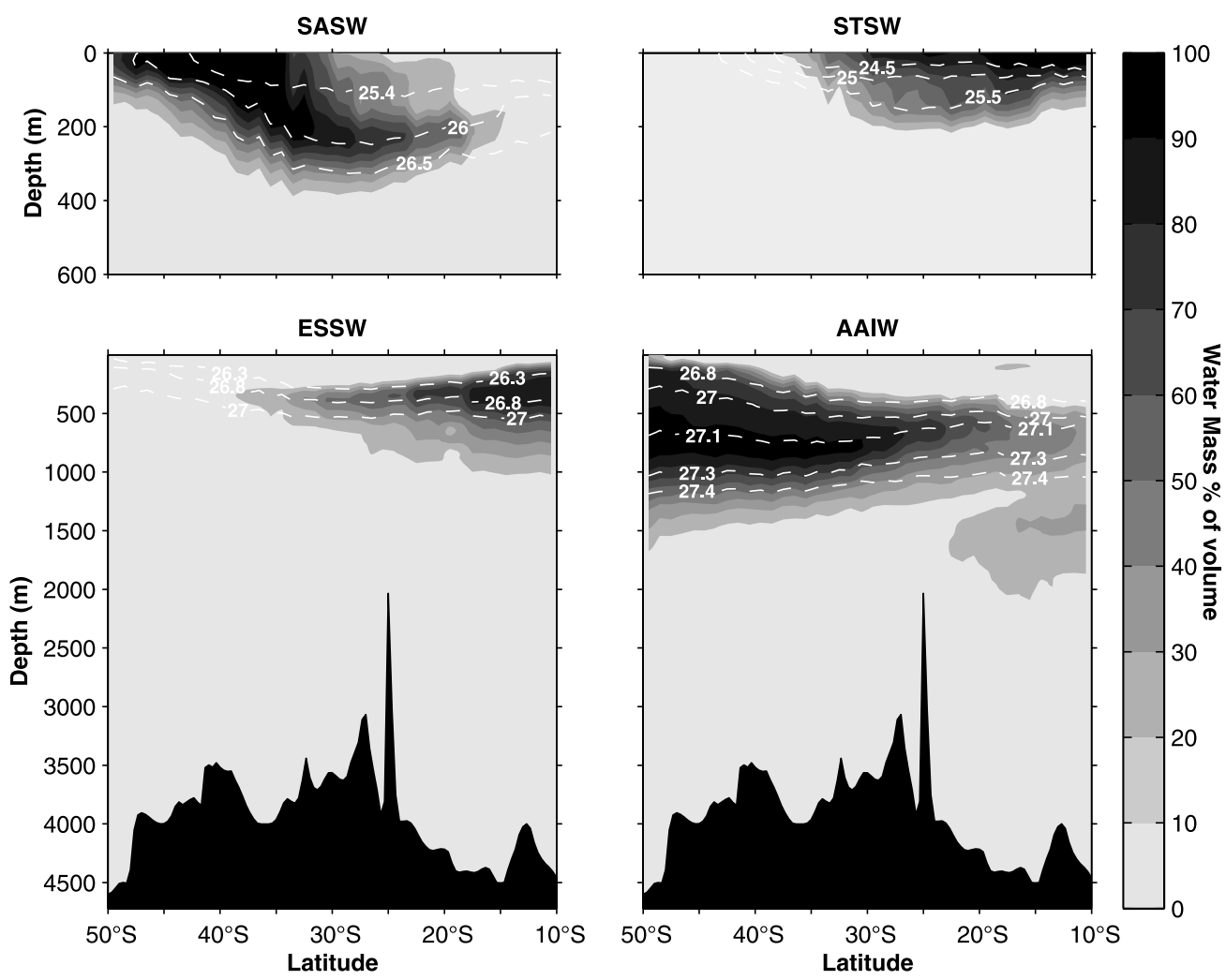

Figure 3. Water mass distribution along a meridional transect from the World Ocean Circulation Experiment (WOCE) line P19 $\left(88^{\circ} \mathrm{W}\right)$ [Tsuchiya and Talley, 1998]. The shading gradient represents the relative (\%) contribution of a given oceanic volume occupied by a water mass. Results were obtained using the extended optimum multiparameter (OMP) analysis with the source water mass characteristics given in Table 1. (top, left) Subantarctic surface water (SASW) distribution, which after being subducted around $33-40^{\circ} \mathrm{S}$, centered at the $26 \mathrm{~kg} \mathrm{~m}^{-3}$ density surface as the eastern South Pacific intermediate water (ESPIW) [Schneider et al., 2003]. (top, right) Subtropical surface water (STSW) distribution. (bottom, left) Equatorial subsurface water (ESSW) distribution. (bottom, right) Antarctic intermediate water distribution. Note that at this longitude $\left(88^{\circ} \mathrm{W}\right)$ the Antarctic intermediate water (AAIW) characteristics are almost indistinguishable from those of the subantarctic mode water (SAMW) [Tsuchiya and Talley, 1998]. The data were downloaded from the WOCE-WHP Web site.

from the poleward advection of the OMZ waters by the poleward Peru-Chile undercurrent [Wooster and Gilmartin, 1961]. This situation is analogous to the ENP, where the California undercurrent brings denitrified oxygen-deficient waters toward higher northern latitudes [Castro et al., 2001]. The lower part of the permanent thermocline is occupied by the Antarctic intermediate water (AAIW), which at this side of the Pacific is intimately linked to the subantarctic mode water (SAMW), from which it is derived during winter at far locations of the ESP west of the Drake Passage [McCartney, 1977; Molinelli, 1981; Toggweiler et al., 1991]. The meridional representation of this rather complicated thermocline structure can be constructed by mapping the percentage of a given volume of the ocean occupied by each individual water mass (Figure 3). We have used the extended optimum multiparameter analysis [Karstensen and Tomczak, 1997] applied to high-quality hydrographic data of the World Ocean Circulation Experiment (WOCE) using the source water characteristics given in Table 1.

[9] Figure 3 illustrates that the low-oxygen waters, associated with the ESSW, are advected poleward by the Peru-
Chile undercurrent. The main core of the ESSW lies between the 26.3 and $27.0 \mathrm{~kg} \mathrm{~m}^{-3}$ potential density range $(\sim 150-$ $500 \mathrm{~m}$ at $\left.88^{\circ} \mathrm{W}\right)$, where it reaches as far south as $30^{\circ} \mathrm{S}$ at $88^{\circ} \mathrm{W}$. The latitudinal extent of the ESSW increases toward

Table 1. Source Water Type Characteristics Used During the Optimum Multiparameter Analysis of Water Mass Percentage Contribution

\begin{tabular}{lllll}
\hline \multicolumn{1}{c}{ Parameter } & STSW $^{\mathrm{a}}$ & $\mathrm{SASW}^{\mathrm{b}}$ & $\mathrm{ESSW}^{\mathrm{c}}$ & AAIW $^{\mathrm{d}}$ \\
\hline Temperature, ${ }^{\circ} \mathrm{C}$ & 24 & 12 & 10 & 4.8 \\
Salinity & 35.5 & 34.2 & 34.8 & 34.2 \\
Oxygen, $\mu \mathrm{mol} \mathrm{kg}^{-1}$ & 215 & 270 & 20 & 280 \\
Nitrate, $\mu \mathrm{mol} \mathrm{kg}^{-1}$ & 0.2 & 12 & 32 & 28 \\
Phosphate, $\mu \mathrm{mol} \mathrm{kg}^{-1}$ & 0.2 & 1.1 & 2.8 & 1.7 \\
Silicate, $\mu \mathrm{mol} \mathrm{kg}^{-1}$ & 0.1 & 2 & 25 & 20 \\
\hline
\end{tabular}

${ }^{\text {a STSW }}=$ subtropical surface water.

${ }^{\mathrm{b}} \mathrm{SASW}=$ subantarctic surface water.

${ }^{\mathrm{c}} \mathrm{ESSW}=$ equatorial subsurface water.

${ }^{\mathrm{d}} \mathrm{AAIW}=$ Antarctic intermediate water. 
the coast where its characteristics can be observed as far south as $40^{\circ} \mathrm{S}$. In contrast, the nearby subducted ESPIW is recognized by high-oxygen and low-salinity contents, and according to Figure 3, it ventilates a thin subsurface layer which falls within $25.8-26.3 \mathrm{~kg} \mathrm{~m}^{-3}$ density range. Because of a severe lack of data, the flow path and mechanisms responsible for the thermocline ventilation in the area and the formation and hydrographic characteristics of the ESPIW have been only recently identified [Karstensen, 2004; Schneider et al., 2003]. Briefly, the salinity minimum is attained by a combination of slow mixed layer velocities in the southern, eastward branch of the South Pacific subtropical gyre [Karstensen, 2004] and increasingly higher precipitation regimes near South America [Dávila et al., 2002]. The formation region can be linked to the outcrop of the shallow salinity minimum at the region south of $38^{\circ} \mathrm{S}$ [Schneider et al., 2003]. It is formed by the process of subduction in the region of negative Ekman pumping velocities over the outcropping density surfaces. During austral winter, the deepening of the mixed layer due to surface cooling and the extension of the $11-13^{\circ} \mathrm{C}$ temperature band to the outcropping region triggers the subduction and formation of the ESPIW. Similar to what occurs with the AAIW, the ESPIW presently communicates surface properties from the region between the subantarctic and subtropical fronts to lower latitudes, but at shallower depths. Particularly relevant to this study is that today, the ESPIW ventilates a very thin layer of the subtropical ESP above the OMZ (see Figure 1a of Schneider et al. [2003] and Figure 3 of this study), where the maximum oxygen concentrations are associated with the salinity minimum (Figure 2, inset). In our opinion, this relationship is a key element related with the past changes of the $\mathrm{OMZ}$, since the water mass configuration shown in Figure 3 was, most likely, very different during glacial times [De Pol-Holz et al., 2006].

\section{Material and Methods}

\subsection{Analysis}

[10] Total nitrogen and organic carbon weight percent composition (TN and TOC wt. \%) and stable isotope ratios $\left(\delta^{15} \mathrm{~N}, \delta^{13} \mathrm{C}_{\text {org }}, \delta=\left(\mathrm{R}_{\text {sample }} / \mathrm{R}_{\text {reference }}-1\right) \times 1000\right.$, where $\mathrm{R}$ is the ratio of the heavy to light isotope) were measured on the bulk sediments of the gravity core GeoB 7139-2 [Mohtadi and Hebbeln, 2004]. The core was sampled at $1 \mathrm{~cm}$ spacing using a " $U$ " channel on the working half of the core. For nitrogen determinations, the sediment was freeze dried and grounded in an agate mortar prior to weighing and subsequent folding in a tin cup. To determine the organic carbon content, the sediment was decalcified adding few droplets of $\mathrm{HCl}(2 \mathrm{~N})$ directly to a silver cup. Each time, 20 to $30 \mathrm{mg}$ of sediment were weighted and combusted in a Thermo Finnigan Flash EA1112 Elemental Analyzer coupled to a Thermo Finnigan Delta Plus Isotope Mass Spectrometer in continuous flow mode via a $\mathrm{CON}$ FLO III interface. Normalization to the international $\delta^{15} \mathrm{~N}_{\text {Air }}$ and $\delta^{13} \mathrm{C}_{\mathrm{V}-\mathrm{PDB}}$ scale was done by running internal laboratory standards (Acetanilide, Atropine and NRC PACS-2) after every fourth sample. Laboratory standards were calibrated against international isotope reference material
(IAEA-N1, IAEA-N2 and IAEA-NO-3; NBS-22, IAEA$\mathrm{CH}-6)$. Isotopic reproducibility was better than $\pm 0.2 \%$. All samples were analyzed at the Universidad de Concepción stable isotope facility. Core top $\delta^{15} \mathrm{~N}$ measurements in GeoB $7139-2$ yielded very similar values to modern surface $\delta^{15} \mathrm{~N}$ as measured previously on multicore samples coming from the study area [Hebbeln et al., 2000].

[11] In addition to the $\mathrm{TN}$ and TOC sediment weight composition, we have calculated the specific vertical fluxes by way of the ${ }^{230} \mathrm{Th}_{\mathrm{ex}}$ normalization method [Francois et al., 2004] in selected samples. A complete description of the methodology is given elsewhere [Dezileau et al., 2004]. The ${ }^{230} \mathrm{Th}_{\mathrm{ex}}$ normalization permits the separation of the vertical flux component from the total mass accumulation and thus is a robust proxy of local primary production in areas that are subject to sediment redistribution (focusing and winnowing) by bottom currents. Thorium and uranium determinations were made by $\alpha$ spectrometry at the Laboratoire des Sciences du Climat et de l'Environnement, CNRS/CEA, Gif-sur-Yvette, and at the Géosciences Montpellier, Université Montpellier 2, France.

[12] A Finnigan MAT 251 mass spectrometer was used to extend the already published $0-40 \mathrm{ka}$ stable oxygen isotope record of core GeoB 7139-2 [Mohtadi and Hebbeln, 2004]. Following the same procedure, twenty individual tests of the planktonic foraminifera Neogloboquadrina pachyderma sin. or $N$. pachyderma dex. $(>150 \mu \mathrm{m})$, depending on abundances, were picked for each measurement. The isotopic composition of the carbonate sample was measured on the $\mathrm{CO}_{2}$ gas evolved by treatment with phosphoric acid at a constant temperature of $75^{\circ} \mathrm{C}$. For all stable oxygen isotope measurements, a working standard (Burgbrohl $\mathrm{CO}_{2}$ gas) was used, which has been calibrated against the Peedee Belemnite (PDB) by using the National Bureau of Standards (NBS) 18, 19 and 20 standards. Consequently, all $\delta^{18} \mathrm{O}$ data given here are relative to the V-PDB standard. Analytical standard deviation is about $\pm 0.07 \%$ o (Isotope Laboratory, Department of Geosciences, University of Bremen, Germany).

[13] Spectral analysis was done using the REDFIT program [Schulz and Mudelsee, 2002]. REDFIT was developed to estimate the power spectrum and the red noise from uneven spaced time series, such as most of paleoceanographic records.

\subsection{Stratigraphy}

[14] The age model of the gravity core GeoB 7139-2 between 0 and $40 \mathrm{ka} \mathrm{B}$. P. is constrained by eight ${ }^{14} \mathrm{C}$-AMS dating points [Mohtadi and Hebbeln, 2004], which were translated into calendar years using the CalPal 2004 January calibration curve (http://www.calpal.de) using a constant reservoir age of 400 years [De Pol-Holz et al., 2006]. For ages beyond $40 \mathrm{ka} \mathrm{B}$. P. we used the planktonic foraminifera $\delta^{18} \mathrm{O}$ record, in which the presence of the marine isotope stage (MIS) 3.31 (55.5 ka B. P.), the MIS 3/4 boundary ( 59 ka B. P.), and the MIS 4.2 substage (65 ka B. P.) [Martinson et al., 1987] close to the base of the record, were apparent (Figure 4, top, and Table 2). By extrapolation of the last computed sedimentation rate, the oldest part of the core was estimated to be near $70 \mathrm{ka} \mathrm{B}$. P. Thus the mean 

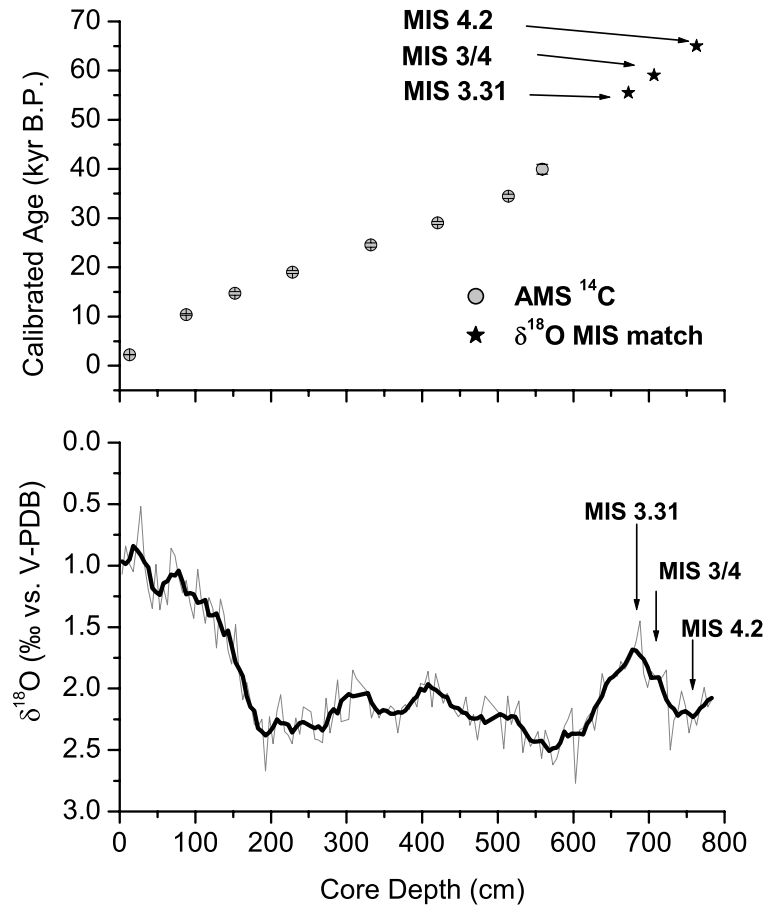

Figure 4. Age model for sediment core GeoB 7139-2. (top) Composite of the age control points: (open circles) calibrated AMS ${ }^{14} \mathrm{C}$ dates with error bars; (solid stars) estimated depths of marine isotope stages $3.11,3 / 4$, and 4.2 ; (bottom) $\delta^{18} \mathrm{O}$ curve of the planktic foraminifera Neogloboquadrina pachyderma (dex. and sin.) against core depth. The thicker solid line is a 5-point moving average that was used to infer the positions of the marine isotope stage (MIS) 3.11 (55.5 ka B. P.), MIS 3/4 (59 ka B. P.), and MIS 4.2 (65 ka B. P.) [Martinson et al., 1987].

time resolution of the $\delta^{15} \mathrm{~N}$ data at the $1-\mathrm{cm}$ interval is $\sim 83$ years.

\section{Results}

[15] Our primary proxy data are the nitrogen isotopic composition of bulk organic matter of sediment core GeoB 7139-2. The reconstruction covers the last $\sim 70 \mathrm{ka}$ with a mean resolution of $\sim 83$ years. The $\delta^{15} \mathrm{~N}$ values range between minimum values of $6.9 \%$ near $31 \mathrm{ka} \mathrm{B}$. P., and $13.9 \%$ at $15 \mathrm{ka} \mathrm{B}$. P. representing the deglacial maximum [De Pol-Holz et al., 2006]. The record shows substantial changes throughout MIS 2 to 4 with a sharp transition from low to high values at the early stages of the deglaciation (Figure 5). The dramatic and abrupt shift in the OMZ intensity at the deglaciation was described and discussed in De Pol-Holz et al. [2006]. During the glacial portion of the record, pronounced $\delta^{15} \mathrm{~N}$ minima are found at $\sim 17.5$, $25,31,45$, and $58 \mathrm{ka} \mathrm{B}$. P. with values of $\sim 7.5 \%$. Likewise, prominent $\delta^{15} \mathrm{~N}$ maxima with values of $\sim 9.5-11.3 \%$ are found at 29, 36, 56 and $70 \mathrm{ka} \mathrm{B}$. P. The Holocene portion of the record starts with decreasing values after the early deglacial $\delta^{15} \mathrm{~N}$ maximum. This trend continues to an inflection point at $\sim 7 \mathrm{ka} \mathrm{B}$. P., reaching a minimum value of
$10.3 \%$ to be followed by an increasing trend toward present values of $11.5 \%$ [De Pol-Holz et al., 2006].

[16] Unlike $\delta^{15} \mathrm{~N}$, the $\delta^{13} \mathrm{C}_{\text {org }}$ results vary little throughout the record with values bounded in the range of -20 to $-22 \%$ and a mean close to $-21 \%$ o (Figure 5). The low variability is expressed in a relatively small standard deviation of $0.4 \%$. There are no clear differences either between glacial and interglacial values or during the MIS $2 / 3$ and $3 / 4$ transitions.

[17] Sedimentary TOC and TN contents are well correlated during the last $70 \mathrm{ka}$. There exist large differences between MIS 1 and 2 in the TOC and TN contents as well as between MIS 2 and 3 (Figure 5). Lowest values are found during MIS 2, while the Holocence and the late part of MIS 3 (26-32 ka B. P.) show similar relatively high values. TOC and TN contents are relatively steady throughout the early and middle portions of MIS 3 . The MIS 4 is characterized by higher TOC and TN contents near $68 \mathrm{ka}$ B.P followed by a progressive decrease to a local minimum at the MIS 3/4 boundary.

[18] The normalization of the TOC content with the ${ }^{230} \mathrm{Th}$ excess method gives us an overall picture of how specific TOC vertical fluxes varied through time avoiding potential flaws, such as sediment redistribution by bottom currents. Overall, the lower resolution Th-normalized TOC fluxes show a similar time evolving structure than the TOC content itself.

\section{Interpretation}

[19] The interpretation of our downcore $\delta^{15} \mathrm{~N}$ record requires an examination of the potential factors affecting the nitrogen isotope composition of the sediments at $30^{\circ} \mathrm{S}$ and at $3200 \mathrm{~m}$ water depth. Among them are: the contributions of isotopically lighter terrestrial-borne organic [Peters et al., 1978; Sweeney and Kaplan, 1980] and inorganic nitrogen [Schubert and Calvert, 2001], changes in the degree of nitrate utilization at the surface by phytoplankton [Altabet and Francois, 1994], isotopic alteration during the particle settling to the ocean floor and during early diagenesis [Haake et al., 2005], and finally, changes in the isotopic composition of the upwelled nitrate.

Table 2. Details on Age Control Points Used to Construct the Age Model of GeoB 7139-2, Chile Margin

\begin{tabular}{lcccc}
\hline $\begin{array}{c}\text { Core } \\
\text { Depth, cm }\end{array}$ & $\begin{array}{c}{ }^{14} \text { C AMS Age, } \\
\text { years B.P. }\end{array}$ & $\begin{array}{c}\text { Ealibrated } \\
\text { years }\end{array}$ & $\begin{array}{c}\text { Age, calendar } \\
\text { years B.P. }\end{array}$ & Method \\
\hline 13 & 2645 & \pm 40 & 2250 & AMS ${ }^{14} \mathrm{C}$ dating \\
88 & 9650 & \pm 80 & 10,410 & AMS ${ }^{14} \mathrm{C}$ dating \\
152.5 & 12,960 & \pm 80 & 14,710 & AMS ${ }^{14} \mathrm{C}$ dating \\
228.5 & 16,490 & \pm 80 & 19,030 & AMS ${ }^{14} \mathrm{C}$ dating \\
332 & 21,630 & \pm 120 & 24,550 & AMS ${ }^{14} \mathrm{C}$ dating \\
420.5 & 25,470 & \pm 220 & 29,030 & AMS ${ }^{14} \mathrm{C}$ dating \\
514 & 30,600 & \pm 420 & 34,450 & AMS ${ }^{14} \mathrm{C}$ dating \\
559 & 36,160 & \pm 1210 & 39,970 & AMS ${ }^{14} \mathrm{C}$ dating \\
673 & & & 55,450 & MIS $3.31^{\mathrm{a}}$ \\
707 & & & 59,000 & MIS $3 / 4^{\mathrm{a}}$ \\
753 & & & 65,000 & MIS $4.2^{\mathrm{a}}$ \\
\hline
\end{tabular}

${ }^{\mathrm{a}}$ After Martinson et al. [1987]. 


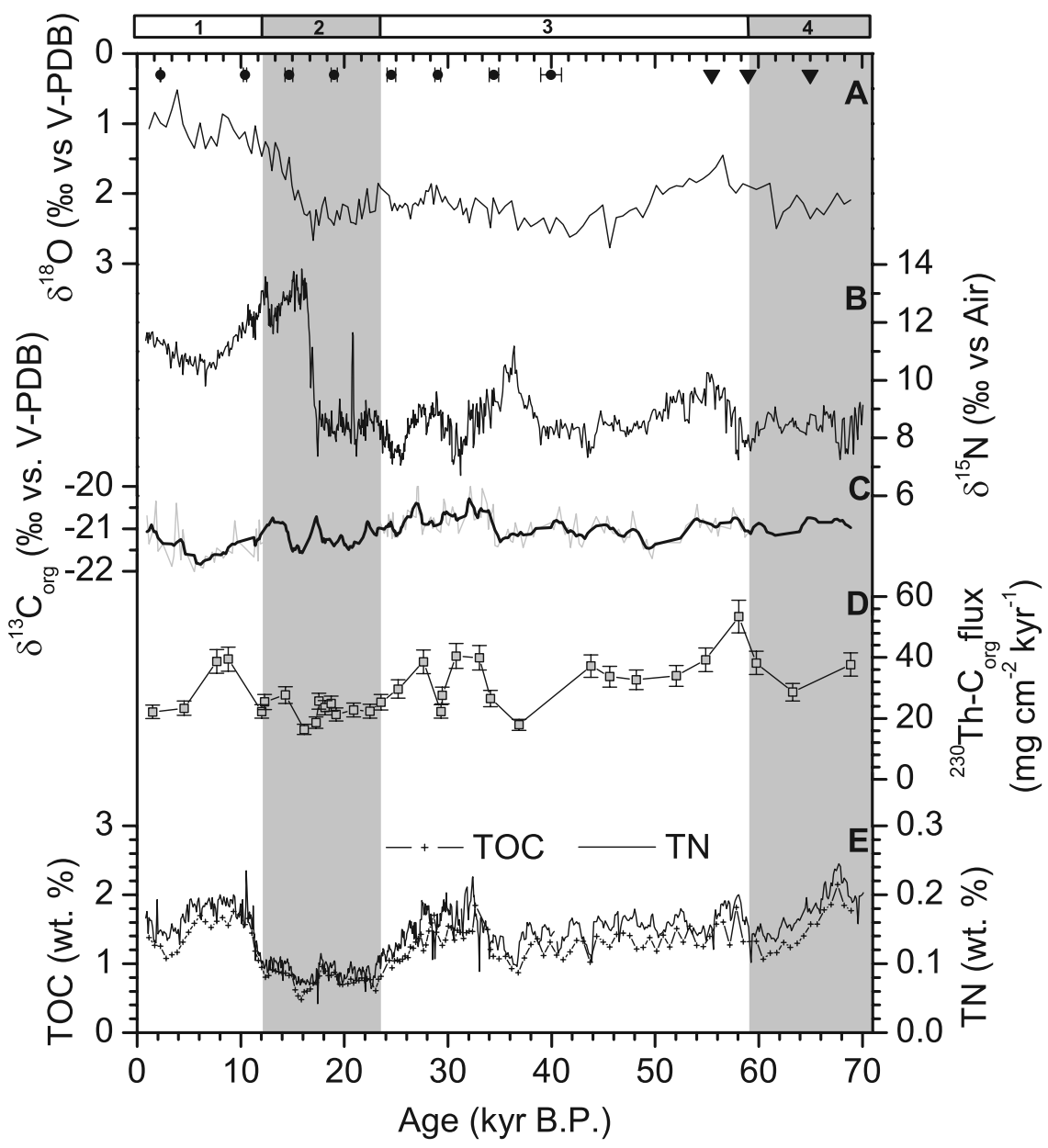

Figure 5. Results from the GeoB 7139-2 sediment core off northern Chile. (a) $\delta^{18} \mathrm{O}$ of the planktic foraminifera Neogloboquadrina pachyderma (dex. and $\sin$.); (b) $\delta^{15} \mathrm{~N}$ of bulk sediments; (c) $\delta^{13} \mathrm{C}_{\text {org }}$ (thick solid line is a 5-point running mean); (d) ${ }^{230}$ Th-corrected vertical $\mathrm{C}_{\text {org }}$ flux (with a $10 \%$ error envelope) [Dezileau et al., 2004]; and (e) total organic carbon (TOC) and total nitrogen (TN) weight percent composition of the sediments. Marine isotope stages 1-4 are shaded.

[20] The sediment bulk composition in core GeoB 7139-2 consists mainly of brown olive to light olive clayey silts and silty clays of terrigenous origin and were deposited under hemipelagic processes [Mohtadi and Hebbeln, 2004]. It has been shown than terrestrial organic material is characterized by relatively light $\delta^{15} \mathrm{~N}$ values ( $\sim 2 \%$ [Sweeney and Kaplan, 1980]) and therefore different admixtures of this material could influence the downcore $\delta^{15} \mathrm{~N}$ record. However, the nearby coastal sites in northern Chile are semiarid, with modern precipitation rates of $\sim 80 \mathrm{~mm}$ year, which promotes desert vegetation (http://www.meteochile.cl). We would therefore anticipate a very minor contribution of terrestrial organic matter, at least during arid periods like the late Holocene. For precessional maxima however, like the LGM, the evidence indicates that the area was significantly wetter, with increased river runoff and terrestrial input to the coastal ocean [Dezileau et al., 2004; Lamy et al., 1998a]. Increased precipitation in the area could have promoted a change in the inland vegetation and thus greater contribution of terrestrial organic matter. Despite this, the downcore $\delta^{13} \mathrm{C}_{\text {org }}$ values are in the narrow range of -20 to
$-22 \%$ (Figure 5), which represent typical values for midlatitude marine-borne organic matter [Fontugne and Duplessy, 1981; Rau et al., 1989]. The absence of longterm periodicity or a glacial-interglacial difference in our $\delta^{13} \mathrm{C}_{\text {org }}$ record suggests that, even during the wetter periods, there was no significant influence of terrestrial-derived organic matter in the site and thus we expect negligible alteration of the sedimentary $\delta^{15} \mathrm{~N}$ because of this factor.

[21] Inorganic nitrogen adsorbed into clay minerals, particularly onto illite crystals, is known to be present in almost all deep sea samples in varying proportions, and it can sum up to $75 \%$ of the total nitrogen content in the sample [Müller, 1977]. Ammonium $\left(\mathrm{NH}_{4}^{+}\right)$substitutes for $\mathrm{K}^{+}$in the interlayer exchange site of illite, with a very constrained isotopic signature that is attained, most likely, on land [Schubert and Calvert, 2001]. Thus downcore $\delta^{15} \mathrm{~N}$ measurements on bulk sediments could be altered by different proportions of clay mineral content and mineralogy. Yet surface sediment data from $30^{\circ} \mathrm{S}$ at a nearby site with similar water depth (GeoB 3368-4) were found to contain $30.5 \%$ content of clay minerals of which $17.1 \%$ was illite 
[Lamy et al., 1998b], thus anticipating only a minor ( $5 \%)$ contribution from land-derived inorganic nitrogen today in the bulk sedimentary TN. Past variations of this proportion are expected to be minor also, as suggested by downcore variations in the clay mineralogy of a nearby core $\left(27.3^{\circ} \mathrm{S}\right)$ [Lamy et al., 1998a]. Furthermore, illite-bond inorganic nitrogen is characterized by a relatively light $\delta^{15} \mathrm{~N}$ value of 1-3\%o [Schubert and Calvert, 2001], so its presence in larger proportions would tend to decrease the overall high $\delta^{15} \mathrm{~N}$ values in our core. However, despite maxima in illite relative content showed a marked precessionality at $27.3^{\circ} \mathrm{S}$ [Lamy et al., 1998a], $\delta^{15} \mathrm{~N}$ minima in our record did not (see below). Therefore we discard the potential effect of inorganic nitrogen isotopic composition in modulating the observed downcore $\delta^{15} \mathrm{~N}$ variability.

[22] Another possible factor affecting sedimentary $\delta^{15} \mathrm{~N}$ variation involves changes in the degree of nitrate utilization by phytoplankton. Fractionation of nitrogen isotopes during the assimilative reduction of nitrate promotes the enrichment in ${ }^{15} \mathrm{~N}$ of the unused pool. If the nitrate residence time in the euphotic zone is sufficiently long, the degree of consumption of nitrate will generate an isotopic signal that will be attained by the newly formed organic particles and that will eventually reach the sea floor. As previously reported [Altabet and Francois, 1994; Farrell et al., 1995; Sigman et al., 1999], the spatial correlation between mean annual surface nitrate content and surface sediment $\delta^{15} \mathrm{~N}$ is a consistent feature of the modern Southern Ocean and equatorial Pacific, two areas of the global ocean characterized by high input of upwelled nitrate and incomplete nitrate consumption due to a limitation of biological productivity by iron availability. If this pattern varies with time, it will produce downcore variations in $\delta^{15} \mathrm{~N}$ as those reported for the Benguela current system [Holmes et al., 1997]. Although Hebbeln et al. [2000] applied this argument as the cause of the large $\delta^{15} \mathrm{~N}$ enrichment trend observed in surface sediment samples along the Chilean margin, current data do not support the idea of a significant unused nitrate fraction remaining at the euphotic zone on an annual basis [Conkright et al., 2002]. This is even less likely in a dustier glacial epoch with more iron availability [Ganeshram et al., 2000].

[23] Given the depth of our site $(>3200 \mathrm{~m})$, isotopic alterations during the particle sinking and due to early sedimentary diagenesis are expected to operate, as shown in experimental as well as in situ data [Altabet and Francois, 1994; Altabet et al., 1999; Freudenthal et al., 2001; Lehmann et al., 2002]. Besides that experimental evidence has documented both enrichment and depletion of $\delta^{15} \mathrm{~N}$ during these processes, it has also highlighted the importance of redox conditions and sedimentation rates as key factors controlling the magnitude of the isotopic effect. More importantly, should these processes or rates vary with time, they may drive downcore variations in the $\delta^{15} \mathrm{~N}$ record in a highly unpredictable way [Haake et al., 2005]. In a companion work, we have addressed this issue by showing that there are no significant differences between the surface sediment's and subsurface nitrate's $\delta^{15} \mathrm{~N}$ values along the northern and central parts of the Chilean margin (R. De Pol-Holz et al., Controls of sedimentary N isotopes along the Chile margin, submitted to Deep Sea Research,
Part II, 2006, hereinafter referred to as De Pol-Holz et al., submitted manuscript, 2006). The absence of a diagenetic imprint was expected because of the relatively high sedimentation rates along the Peru-Chile margin [Muñoz et al., 2004], in line with the findings of Altabet et al. [1999] and Francois et al. [1997] that showed no isotopic effects on $\delta^{15} \mathrm{~N}$ values for areas with moderate to high sedimentation rates. Moreover, because of the depth of the study site, we expect almost unchanged redox conditions for the relatively short time span of our record. Thus we find very unlikely that the downcore $\delta^{15} \mathrm{~N}$ variability in our record is due to changing diagenetic effects.

[24] Yet, $\delta^{15} \mathrm{~N}$ values throughout the GeoB7139-2 core are significantly higher than the present-day mean oceanic nitrate $\left(\delta^{15} \mathrm{~N}\right.$ of $5-6 \%$ [Sigman et al., 1997]) and considerably higher than sediments from off southern Peru at a similar water depth [Ganeshram et al., 2000]. Having ruling out local effects as the cause for $\delta^{15} \mathrm{~N}$ values and variability in our record, we now discuss the effect of the isotopic composition of nitrate that feed the upwelling system of northern and central Chile as the most likely factor controlling both the $\delta^{15} \mathrm{~N}$ value today and its variability through time.

[25] The intricate thermocline structure of the ESP (presented in section 2) complicates the evaluation of the potential source of nitrate to our site. As depicted in Figure 3, and assuming that the contribution of the relatively nutrient free STSW is very minor, there are three potential sources of subsurface nitrate for phytoplankton growth at $30^{\circ} \mathrm{S}$, namely the northern-sourced ESSW, and the southernsourced ESPIW and AAIW (SAMW). Consistent with surface data from the Southern Ocean region [Sigman et al., 1999], the nitrate $\delta^{15} \mathrm{~N}$ at the core of AAIW in our region is significantly lower (7\%o) (De Pol-Holz et al., submitted manuscript, 2006) than surface sediment $\delta^{15} \mathrm{~N}$ in the region ( 11.5\%o) [Hebbeln et al., 2000]. Therefore, and considering the fact that AAIW occupies a considerable deep layer in the water column, we find that it is unlikely that this water mass could be a significant source of nitrate for upwelling in our study site.

[26] Instead, at shallower depths, the ESPIW's preformed nitrate is theoretically derived from the unused pool of subantarctic surface water that subducts south of the subtropical front [Schneider et al., 2003]. These waters should bear a nitrate $\delta^{15} \mathrm{~N}$ signature of $5-7 \%$ when they are part of the Antarctic circumpolar current in the Southern Ocean (north of the subantarctic front) [Sigman et al., 1999]. However, this signature should become progressively heavier as nitrate is advected northward and consumed by phytoplankton along the surface displacement of the ChilePeru current, especially when it intersects the highly productive upwelling centers off central Chile. This is likely the explanation of the northward enrichment in surface sediment's $\delta^{15} \mathrm{~N}$ off southern and central Chile [Hebbeln et al., 2000; De Pol-Holz et al., submitted manuscript, 2006]. However, farther to the north of the subtropical front, once subantarctic waters have subducted in the form of ESPIW, its nitrate concentration becomes extremely low and its $\mathrm{N}$ isotopic composition suggest that rather the long-range transport of preformed nutrients from the south, its nitrate content is most likely the result of local processes, i.e., the 
regeneration of organic matter and vertical supply from the underlying ESSW (De Pol-Holz et al., submitted manuscript, 2006). Thus although for the present-day situation the ESPIW nitrate $\delta^{15} \mathrm{~N}$ would fit within the surface sediment $\delta^{15} \mathrm{~N}$ values at our site, we favor the widespread idea that nutrients at our site have their remote origin in the core of the $\mathrm{OMZ}$, in analogy to the California current system [Castro et al., 2001; Liu and Kaplan, 1989]. One implication of our interpretation is that the high value of core top $\delta^{15} \mathrm{~N}$ is the direct consequence of the isotopic effect of NR within the OMZ. The first step in the NR pathways $\left(\mathrm{NO}_{3}^{-}\right.$reduction to $\left.\mathrm{NO}_{2}^{-}\right)$, is characterized by an important kinetic isotopic fractionation that leaves the unused $\mathrm{NO}_{3}^{-}$ fraction enriched with the heavy ${ }^{15} \mathrm{~N}$ isotope [Cline and Kaplan, 1975]. Vertical transport mechanisms like upwelling and/or mixing will bring the enriched $\mathrm{NO}_{3}^{-}$to the photic zone where it is assimilated by phytoplankton, leading to a downward flux of organic matter that carries the NR signal to the ocean floor. When sediment organic matter is well preserved, like in high-accumulation-rate settings, the down core ${ }^{15} \mathrm{~N}$ record provides an faithful indication for past changes in water column NR [Altabet et al., 1999], and hence a proxy for the $\mathrm{OMZ}$ intensity. Indeed, modern sediment $\delta^{15} \mathrm{~N}$ values at our site $(\sim 11.5 \%)$ [Hebbeln et al., 2000; De Pol-Holz et al., submitted manuscript, 2006] are undistinguishable from nitrate $\delta^{15} \mathrm{~N}$ at $200 \mathrm{~m}$ (De PolHolz et al., submitted manuscript, 2006) where the core of the ESSW is located (Figure 3). Thus in line with several other paleoceanographic studies at different latitudes in the ESP [Agnihotri et al., 2006; De Pol-Holz et al., 2006; Higginson and Altabet, 2004; Martinez et al., 2006; Robinson et al., 2007], we will interpret the GeoB 7139-2 downcore variations in sedimentary $\delta^{15} \mathrm{~N}$ as representing the NR history of the subsurface waters at the OMZ.

[27] Our interpretation is consistent with the synchronous early deglacial abrupt 5\% increase in sedimentary $\delta^{15} \mathrm{~N}$ in our site and off Peru [De Pol-Holz et al., 2006; Higginson and Altabet, 2004], which suggests a common origin for the signal. Similarly, the lower glacial $\delta^{15} \mathrm{~N}$ values of our core should reflect reduced or even absent NR in the OMZ area as reported for the Peru margin [Ganeshram et al., 2000; Higginson and Altabet, 2004]. Yet, our glacial values are significantly higher (2 to $3 \%$ ) than glacial sediments from the OMZ region and that of mean ocean nitrate [Sigman et al., 1997]. This would point to a different source of nutrients at our site during the well-ventilated glacial ESP. We will discuss further the isotopic difference in our record compared from that off Peru when we propose the mechanism responsible for the NR changes in the ESP.

\section{Discussion}

\subsection{Causes of Variability in the OMZ of the ESP at Millennial Timescales}

\subsubsection{Orbital Forcing or Internal Variability?}

[28] The relatively large-amplitude isotopic changes that characterize our record between 20 and $67 \mathrm{ka} \mathrm{B}$. P. lasted for several millennia. The time window between the three major isotopic maxima at 56, 36 and $16.5 \mathrm{ka} \mathrm{B}$. P. may well express an inherent $20 \mathrm{ka}$ cycle in the $\mathrm{OMZ}$ intensity consistent with orbital forcing. A link between precession and $\delta^{15} \mathrm{~N}$ in our core can be rationalized by three ways. First, Dezileau et al. [2004] found strong agreement between precession and biogenic vertical accumulation rates in a nearby site $\left(27^{\circ} \mathrm{S}\right)$. The connection would be established by the increased oxygen demand at times of higher primary productivity during precession maxima [Dezileau et al., 2004]. Second, an important low-frequency modulation of ENSO has been attributed to precession by modeling experiments [Clement et al., 2000]. They show that insolation changes at low latitudes induce variations in the frequency and intensity of ENSO events. Third, the latitudinal position of the oceanic fronts, upwelling centers, lowpressure systems and the southern westerlies has been also shown to vary with precession [Lamy et al., 1998a]. The latitudinal displacement of those characteristics would tend to alter many other oceanographic features; among them, the active formation area of intermediate water masses is relatively important for the ventilation of the OMZ layer [De Pol-Holz et al., 2006]. It is then important to differentiate how much, if any, of the variability of our data originates from orbital forcing or by internal millennialscale adjustments of the OMZ. For that, we have performed frequency analysis of the GeoB7139-2 $\delta^{15} \mathrm{~N}$ record after having extracted the mean in two different subsets, the first between 0 and $16.5 \mathrm{ka} \mathrm{B}$. P. and the second between 17.5 to $67 \mathrm{ka}$ B. P. The goal here was to remove the effect of the large deglacial $\delta^{15} \mathrm{~N}$ rise in the frequency analysis, which would tend to assign too much energy to lower frequencies. Results from the frequency fit show that the variability in our $\delta^{15} \mathrm{~N}$ record is similar to a theoretical red noise spectrum with a persistence timescale $(\tau)$ of 600 years [Mudelsee, 2002] (Figure 6a). However, in our data, there is significantly less spectral power in the 0.2 to 1 cycles/ka frequency range than in a theoretical red noise spectrum (Figure 6a) precluding an optimum statistical fit with a 5\% significance level [Schulz and Mudelsee, 2002]. Figure 6a shows that there is a peak in spectral power concentrated near the precessional frequency band (20 to $22 \mathrm{ka}$ period), but without the sufficient amplitude as to overcome the critical "false alarm" level of $99.86 \%$ determined for our record [Thomson, 1990]. We will therefore cautiously consider the result of this analysis as an indication that precession was probably not the primary cause of variability for the $\delta^{15} \mathrm{~N}$ in the ESP during the last $70 \mathrm{ka} \mathrm{B}$. P. Additionally, we have plotted the resulting $\delta^{15} \mathrm{~N}$ record, after the extraction of its mean, together with the January (summer) insolation at $15^{\circ} \mathrm{S}$, for visual comparison (Figure $6 \mathrm{~b}$ ). It can be seen that the three $\delta^{15} \mathrm{~N}$ incursions separated by $\sim 20 \mathrm{ka}$ occur during different phases of the insolation curve. Because of the limited time extension of our data, we cannot statistically resolve the obliquity and eccentricity periods, which seem to have played a major role in the glacial-interglacial NR changes as those observed in the three main OMZs [Ganeshram et al., 2000; Liu et al., 2005]. Also, we cannot rule out that for longer time series, the $\sim 20 \mathrm{ka}$ cycle indeed becomes significant. Low $\delta^{15} \mathrm{~N}$ values present during precession maxima, for example, may be an indication that, among the mechanisms discussed above, the displacement of oceanic fronts toward lower latitudes promotes a better 
a)
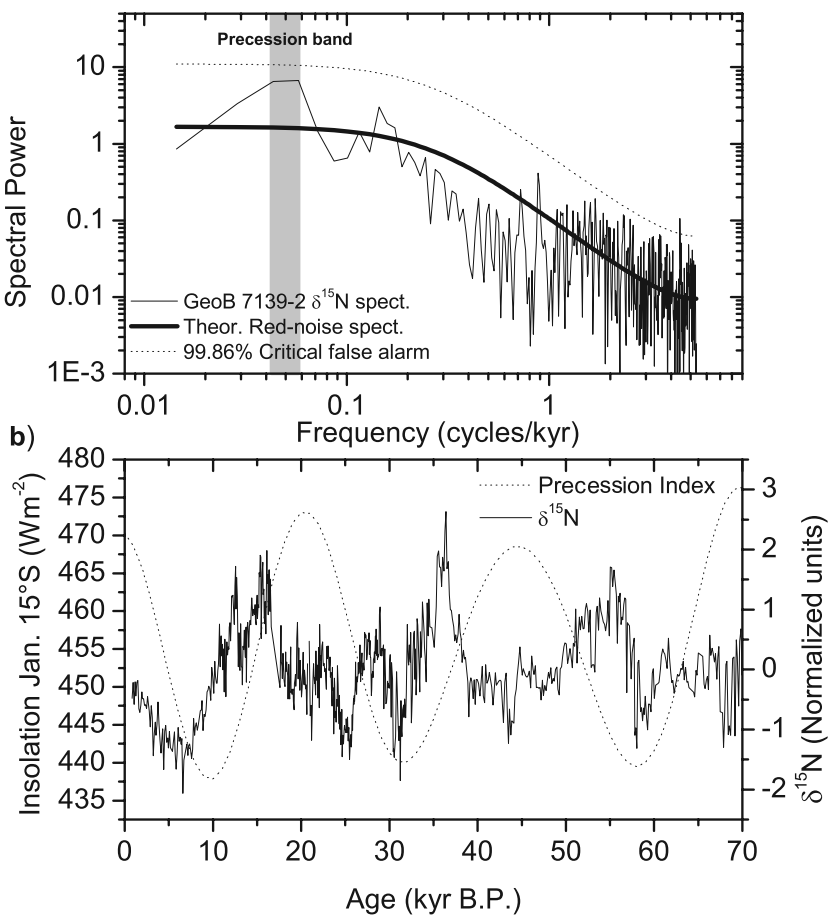

Figure 6. Frequency analysis of the GeoB 7139-2 $\delta^{15} \mathrm{~N}$ record and its relation with precession. (a) Bias-corrected spectrum of the $\delta^{15} \mathrm{~N}$ time series (thin solid line); theoretical red noise spectrum based on the calculated persistency (thick solid line) and "false alarm" level (99.86\%) [Schulz and Mudelsee, 2002]. (b) The resulting GeoB 7139-2 $\delta^{15} \mathrm{~N}$ time series after the extraction of the mean (plotted without scale) compared with the January insolation at $15^{\circ} \mathrm{S}$ (see text for details).

ventilation of the OMZ. We interpret, however, that the $\delta^{15} \mathrm{~N}$ maxima documented in our record are the response to intrinsically suborbital phenomena; i.e., internally forced by millennial-scale climate fluctuations.

\subsubsection{Productivity Versus Ventilation}

[29] Having established that the mode of variability in our $\delta^{15} \mathrm{~N}$ record is dictated most likely by millennial-scale dynamics, we need to assess whether this rhythm was set from productivity-derived oxygen consumption or by remotely forced ventilation processes. Millennial-scale changes in NR in the global ocean have been shown to occur by either shifts in local primary production [Altabet et al., 2002; Emmer and Thunell, 2000], or by variations of the physical processes that determine the formation and ventilation of the intermediate waters at their source area [Higginson and Altabet, 2004; Kienast et al., 2002].

[30] For the ESP, the productivity-driven mechanism was proposed by Ganeshram et al. [2000] as the most probable forcing behind the glacial-interglacial differences in NR. The idea found support in the covariation between their $\delta^{15} \mathrm{~N}$ record and the productivity proxies that they used. More recently, however, Higginson and Altabet, [2004] and De Pol-Holz et al. [2006] challenged that argument by the use of new proxies that showed no relation between productivity and the abrupt rise in $\delta^{15} \mathrm{~N}$ at the beginning of the deglaciation. They proposed instead that changes in the ventilation of the intermediate waters were the most likely alternative to explain the glacial-interglacial difference in the $\delta^{15} \mathrm{~N}$ records of the ESP, albeit invoking different water masses.

[31] In order to discriminate whether the "biological" or the "physical" mechanism was the main precursor of the millennial-scale NR variations in the ESP during the glacial period, we have compared our $\delta^{15} \mathrm{~N}$ record with sedimentary proxies of primary production and ventilation in the ESP. Although the TN or TOC contents of sediments has been commonly used as a proxy for paleoproductivity [Altabet et al., 2002; Ganeshram et al., 2000; Liu et al., 2005], these types of proxies might be affected by dilution processes that can corrupt the productivity signal [Dezileau et al., 2004; Francois et al., 2004]. In order to overcome this problem, we have normalized the biogenic fluxes using the ${ }^{230}$ Th technique [Francois et al., 2004]. This method permits the estimation of the export productivity, which in turn, should be linked with the oxygen demand in the subsurface ocean and affect the NR rates and $\delta^{15} \mathrm{~N}$.

[32] Figure 5 suggested a poor correlation between our productivity proxies and the $\delta^{15} \mathrm{~N}$ record. Periods with elevated $\delta^{15} \mathrm{~N}$ do not consistently coincide with higher biogenic fluxes. The $\delta^{15} \mathrm{~N}$ signal, however, could be more sensitive to changes in the whole area-integrated primary productivity of the ESP, rather than the localized variations of primary productivity that is shown in Figure 5. Unfortunately, until now we do not have a consistent estimate of the whole area-integrated productivity because of the lack of robust records in the ESP system. Thus although we cannot rule out completely the possibility that millennial-scale variability in NR is related to productivity at a regional scale, we will nevertheless examine a potential control of NR by ventilation.

\subsubsection{Ventilation of the OMZ: Low- or High-Latitude Control?}

[33] There is a clear imbalance between the Northern and Southern hemispheres with respect to the number of studies focusing on millennial-scale climate variability during the last glacial period. While the former has been subject to a wide number of studies, data/observations from the $\mathrm{SH}$ are still scarce. Most of what we know about the millennialscale climate changes in the $\mathrm{SH}$ comes from the studies on Antarctic ice cores, which may be representing isolated conditions of Antarctica and not hemisphere-wide features [Moreno et al., 2001]. However, a growing body of evidence shows that the SH's climate at mid to high latitudes responded also to an "Antarctic" timing [Charles et al., 1996; De Pol-Holz et al., 2006; Kaiser et al., 2005; Lamy et al., 2004; Pahnke and Zahn, 2005; Pahnke et al., 2003]. From this perspective, the location of the GeoB 7139-2 site should be considered adequate for documenting tropical and high-latitude forcing [Mohtadi and Hebbeln, 2004]. Since the core of the OMZ is within the tropical band, we expected ventilation changes associated with the ENSOlike tropical Pacific variability. At millennial timescales, evidence show that ENSO-like variability resembles 
Dansgaard/Oeshger events as those recorded in the Greenland ice core records [Koutavas et al., 2002; Stott et al., 2002; Turney et al., 2004]. A connection between an ENSO-like type of variability and the OMZ (expressed as NR intensity) can be expected since during modern El Niño conditions, the thermocline and oxycline depth in the ESP deepen considerably [Morales et al., 1999; Ulloa et al., 2001]; the converse occurs during La Niña conditions. Remotely forced changes in NR intensity have been associated with modern ENSO in the ESP [Codispoti et al., 1988], primarily as a consequence of this vertical displacement and associated reduction of the OMZ's volume [Morales et al., 1999]. Furthermore, those NR changes have been recorded in the $\delta^{15} \mathrm{~N}$ of settling particles, as it was the case for the 1991-1992 El Niño event in the ENP [Altabet et al., 1999]. However, our ESP $\delta^{15} \mathrm{~N}$ record does not resemble Dansgaard/Oeschger events. As discussed in De Pol-Holz et al. [2006], the deglacial portion of the GeoB 7139-2 $\delta^{15} \mathrm{~N}$ record was dominated by an "Antarctic" timing, which distinctly differentiated it from analogous millennial-scale records of the NH. Now, we can extend this conclusion further for the glacial during MIS 3 and 4. These results then set a common $\mathrm{SH}$ mode for atmospheric temperatures [EPICA Community Members, 2004], sea surface temperatures [Kaiser et al., 2005; Lamy et al., 2004] and OMZ intensity in the ESP during the last $70 \mathrm{ka}$. The absence of Dansgaard/Oeschger-like patterns in NR intensity in the ESP during MIS 2 to 4 has implications for the role of lowlatitude forcing on the OMZ. If during the glacial, the millennial-scale ENSO promoted mean oceanographic conditions similar to the interannual analog, sustained periods of ENSO-like warm phases should have been characterized by a deeper thermocline, reduced trade wind activity and reduced equatorial upwelling, resulting in a reduction of the OMZ volume and NR. The opposite would hold for cold phases. Thus low-latitude control of the ventilation of the OMZ appears to be unlikely, leading us to explore for a highlatitude ventilation control.

[34] High-latitude control of the ventilation of the OMZ during the past should be related to the formation rates and history of thermocline waters like SAMW/AAIW and/or ESPIW. De Pol-Holz et al. [2006] showed that the deglacial onset and successive millennial-scale changes of the NR were difficult to explain by assuming that they originating in the Southern Ocean source regions of the SAMW and AAIW. On the contrary, the intermediate waters originated near the subpolar front showed a reinforced ventilation during periods of high NR and vice versa [Bostock et al., 2004; Pahnke and Zahn, 2005; Spero and Lea, 2002]. On this basis, De Pol-Holz et al. [2006] hypothesized that the mechanism behind the abrupt shift in $\delta^{15} \mathrm{~N}$ was probably linked to the closer midlatitude subduction region of the modern eastern South Pacific intermediate water (ESPIW). Today, this water mass occupies and ventilates a thin layer of the upper thermocline (Figure 2). They provided support for their hypothesis by an excellent agreement between the deglacial salinity variations at the source region of the ESPIW off southern Chile and the deglacial OMZ changes at millennial timescales. The mechanism operating behind this tight link is the sensitivity of the ESPIW subduction process to fresh water input from the continent. According to modeling studies and field evidence, during the deglaciation, the melting of the Patagonian ice sheet discharged a fresh water volume of $222 \times 10^{12} \mathrm{~m}^{3}$. We can picture this volume as equivalent to a fresh water cap with an area of $1.11 \times 10^{6} \mathrm{~km}^{2}$ and $200 \mathrm{~m}$ depth. This area would be larger than the modern outcropping region of the ESPIW [Karstensen, 2004; Schneider et al., 2003], and sufficiently deep as to isolate the outcropping density surfaces from the contact of the atmosphere. Furthermore, the deglacial melting occurred in a time window of just about 300 years [Hulton et al., 2002]. Following the same line of reasoning, we suggest that other previous mass fluctuations of the Patagonian ice sheet, although smaller, could have produced significant fresh water pulses that would alter the subduction rates of the ESPIW and thus the ventilation of the OMZ.

[35] In order to assess if there were hydrographic changes at the source area of the ESPIW that could have been associated with the millennial-scale variations of the $\mathrm{OMZ}$ off northern Chile during the last glacial, we have compared our $\delta^{15} \mathrm{~N}$ record with the sedimentary Fe content of the ODP Site 1233 off southern Chile [Kaiser et al., 2005; Lamy et al., 2004]. Unfortunately, direct estimations of paleosalinity off southern Chile are not yet available for the last $70 \mathrm{ka}$. Nevertheless, the sedimentary Fe content of ODP Site 1233 has been interpreted as being the result of glacial erosion processes that strongly enhanced the glaciofluvial sediment flux from Fe-rich basaltic volcanics in the Andes. It is intimately related to the dynamics of the Patagonian ice sheet, since its advances provided more Fe-rich material to be transported by rivers toward the continental margin [Kaiser et al., 2005; Lamy et al., 2004]. It can be seen in Figure 7 that there is millennial-scale coherence between our $\delta^{15} \mathrm{~N}$ record and the sedimentary Fe content at $41^{\circ} \mathrm{S}$. Although the apparent covariance of these records does not constitute a proof of causation, we suggest that it is the manifestation of the changes in the subduction rates of the ESPIW triggered by fresh water pulses derived from the Patagonian Ice Sheet advance and retreat during millennial-scale temperature changes in the SH [Lamy et al., 2004].

[36] This mechanism also serves to explain the relatively elevated $\delta^{15} \mathrm{~N}$ values in our core; despite that the $\mathrm{OMZ}$ volume was well ventilated by the ESPIW and NR was likely absent, as indicated by low glacial $\delta^{15} \mathrm{~N}$ values off Peru [Ganeshram et al., 2000]. A northward displacement of the oceanographic systems and fronts that characterized the glacial would bring the subduction region of the ESPIW nearer to $30^{\circ} \mathrm{S}$ and also nearer to the OMZ. Thus greater ventilation is also indicative that the transport distance of nutrients from the subantarctic region along the Chilean coast was significantly shorter than today. In this scenario, it is likely that surface nutrients were not as depleted as today and hence newly subducted ESPIW would had a measurable preformed nitrate content that will eventually feed the upwelling farther north. By the time this subsurface water reached the Peru upwelling region however, nitrate concentrations would have been extremely low, analogous to the ESPIW off northern Chile today (De Pol-Holz et al., submitted manuscript, 2006). In this scenario, nitrate 


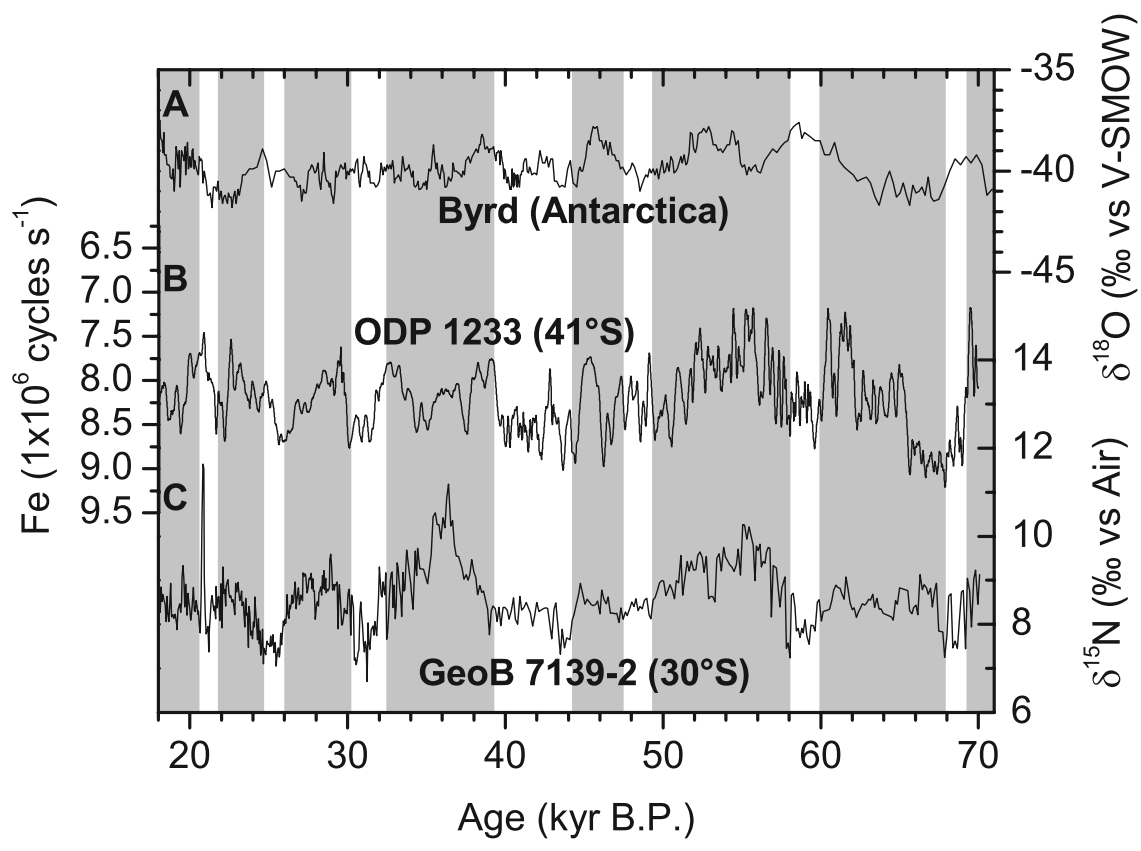

Figure 7. Comparison of geochemical data from northern and southern Chile sediment cores GeoB $7139-2\left(30^{\circ} \mathrm{S}\right)$ and ODP Site $1233\left(41^{\circ} \mathrm{S}\right)$ and Antarctic climate (Byrd ice core) during the last glacial epoch. (a) The $\delta^{18} \mathrm{O}$ of ice in the Byrd ice core; (b) XRF-derived Fe content of ODP Site 1233 (inverse scale); and (c) $\delta^{15} \mathrm{~N}$ record of GeoB 7139-2. Shading represents periods with higher $\delta^{15} \mathrm{~N}$.

upwelled off central and northern Chile during the glacial was preformed and enriched in $\delta^{15} \mathrm{~N}$ because of phytoplanktonic assimilation during the alongshore transport. Off Peru, however, nitrate was most likely the product of mineralization and mixing with underlying waters (SAMW), which in absence of NR would have carried a relatively low $\delta^{15} \mathrm{~N}$ signal. However, if subduction stops, for example as a consequence of a melting pulse off southern Chile, the OMZ would have developed rapidly in the thermocline, promoting water column NR and elevating the $\delta^{15} \mathrm{~N}$ values. This mechanism relies on the presence of two oceanographic components: (1) the subtropical gyre circulation transporting subantarctic waters along the Chilean margin and (2) the presence of the PCU carrying subsurface waters from lower latitudes. We find very unlikely that one of these processes could have stopped completely during the relatively short timescale of our study.

\subsection{NR Variability in the ESP in the Context of the Global NR Changes and Its Implications for the Late Quaternary Nitrogen and Carbon Cycles}

[37] Late Quaternary NR variations in the NH-OMZs are highly correlated with the rapid climate transitions, known as the Dansgaard/Oeschger events, typical of the North Atlantic region during MIS 2 and 3. These rapid climate swings set a common pacing for the NH-NR rates, where warm interstadials were characterized by high NR rates and vice versa [Altabet et al., 2002; Emmer and Thunell, 2000; Suthhof et al., 2001]. In theory, the imbalances between the main source and sink terms in the marine nitrogen cycle, namely the nitrogen fixation [Capone et al., 1997] and NR (denitrification) [Codispoti and Christensen, 1985], can be considered as probable driving agents behind the $\mathrm{CO}_{2}$ variation in the atmosphere at different timescales [Altabet et al., 1995; Altabet et al., 2002; Falkowski, 1997; Ganeshram et al., 1995; McElroy, 1983]. The strength of the biological pump is directly influenced by the availability of nutrients such as $\mathrm{NO}_{3}^{-}$. This fact links the ratio of nitrogen fixation to NR with the ability of the ocean to sequester $\mathrm{CO}_{2}$ from the atmosphere. However, the net effect that an individual OMZ and changes in its NR intensity would have on the oceanic $\mathrm{NO}_{3}^{-}$budget is a complex calculation that depends on, for example, the sum of the relative intensities of the NR process occurring in all OMZs of the ocean and the response exerted by the nitrogen fixation feedback due to changes in the oceanic N:P ratio [Tyrrell, 1999]. We have attempted nevertheless to qualitatively constrain the NR forcing on oceanic $\mathrm{NO}_{3}^{-}$by smoothing the original NR curves with a running mean whose time window corresponds approximately to the residence time of the oceanic $\mathrm{NO}_{3}^{-}$(3000 years [Altabet et al., 2002]). This procedure results in the hypothetical NR forcing on the biological sequestration of $\mathrm{CO}_{2}$, which can then be compared with the atmospheric history recorded in ice cores. This idea was first introduced by Altabet et al. [2002] for the AS. We now include for the first time the contribution of the ESP for a global picture of the potential effect of NR on atmospheric $\mathrm{CO}_{2}$.

[38] In Figure 8 we have marked certain features of these records that resemble the observed variability in the late Quaternary evolution of atmospheric $\mathrm{CO}_{2}$. For example, between $40-60 \mathrm{ka} \mathrm{B}$. P., the $\mathrm{CO}_{2}$ rises about $20 \mathrm{ppmv}$ 


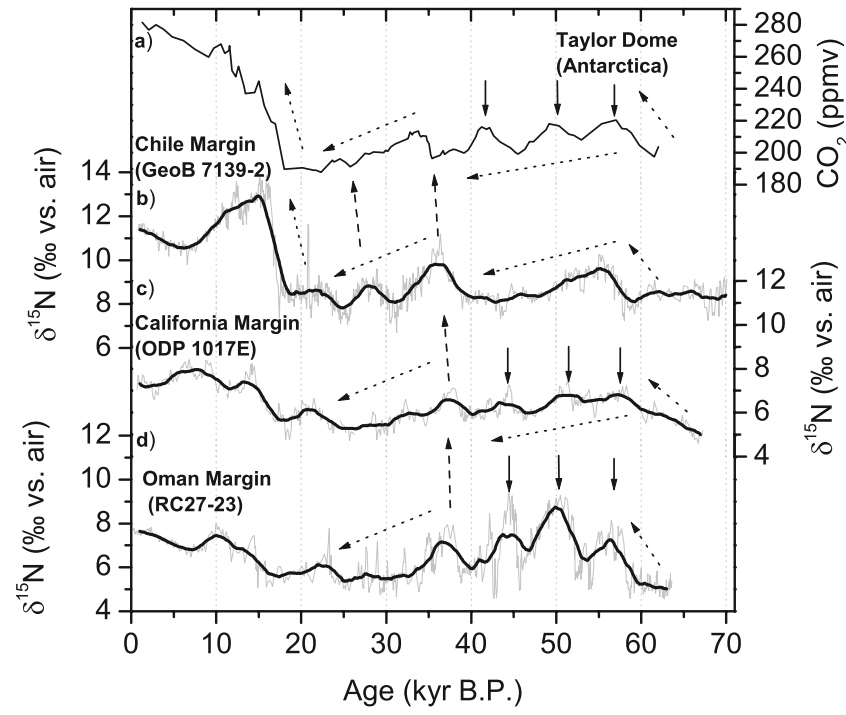

Figure 8. The late Quaternary history of the OMZ intensity in the three areas where modern-day nitrogen removal takes place, compared to the $\mathrm{CO}_{2}$ concentration in the atmosphere. (a) $\mathrm{CO}_{2}$ concentration in the Antarctic Taylor Dome ice core (composite data from Indermühle et al. [2000], Indermühle et al. [1999], and Smith et al. [1999]). (b) The $\delta^{15} \mathrm{~N}$ record of the eastern South Pacific (this study). (c) The $\delta^{15} \mathrm{~N}$ record of the eastern North Pacific [Ganeshram et al., 2000; Hendy et al., 2004; Kienast et al., 2002]. (d) The $\delta^{15} \mathrm{~N}$ record of the Arabian Sea [Altabet et al., 2002]. The light gray lines are the original data set, whereas the solid black line is a 3000 year running mean. See text for details. (depicted with a dashed arrow). This rise was preceded by a persistent increase in the NR intensity in the ENP during 65-55 ka B. P., and by notorious increases in the AS and the ESP at $60 \mathrm{ka} \mathrm{B}$. P. (dashed arrows). This 40-60 ka time window is later characterized by three $\mathrm{CO}_{2}$ incursions with decreasing intensities at $\sim 57,50$ and $43 \mathrm{ka} \mathrm{B}$. P. (marked with solid vertical arrows) that have been previously related to the NR forcing occurring in the AS [Altabet et al., 2002] and also present in the ENP record, however not in the SH. The decreasing intensity of the $\mathrm{CO}_{2}$ incursions between $60-40 \mathrm{ka} \mathrm{B}$. P. might be related to a pronounced decreasing NR trend in the ESP and a moderate decreasing trend in the ENP (dashed arrows). Later, between 20-40 ka B. P., there are two $\mathrm{CO}_{2}$ incursions starting at 35 and $26 \mathrm{ka} \mathrm{B}$. P. Again, these incursions and their longer-term trend could be related to contemporaneous changes in the NR intensity of the three OMZs. Figure 8 shows that the $\mathrm{CO}_{2}$ increase at $35 \mathrm{ka} \mathrm{B}$. P. was preceded by NR maxima in the three OMZs at 36$37 \mathrm{ka} \mathrm{B}$. P. (dashed vertical arrows) and that the smaller $\mathrm{CO}_{2}$ increase at $26 \mathrm{ka} \mathrm{B}$. P. was preceded by a NR maximum in the ESP at $27 \mathrm{ka} \mathrm{B}$. P. The $15 \mathrm{ka}$ decreasing trend in $\mathrm{CO}_{2}$ is also present in the three OMZs (dotted arrows).

[39] All of these features can be summarized by constructing an index of the global NR forcing on atmospheric $\mathrm{CO}_{2}$. The index is simply the sum of the smoothed normalized $\delta^{15} \mathrm{~N}$ data from the three OMZs (Figure 9). The two basic assumptions here are (1) that the isotopic change recorded in sediments is approximately linearly related to the amount of nitrate that is being denitrified above in the water column and (2) that the slope of this linear relation is similar in the three OMZs. The first assumption holds if the reactant $\left(\mathrm{NO}_{3}^{-}\right)$is continuously supplied to and partially consumed at the thermocline, as

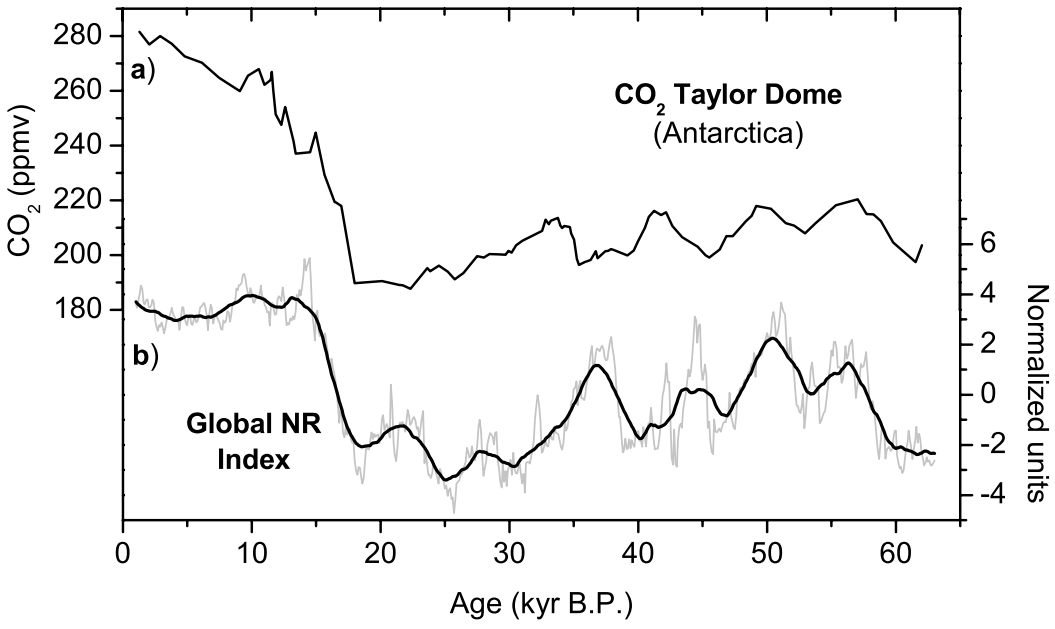

Figure 9. Comparison of the atmospheric $\mathrm{CO}_{2}$ concentration from the Taylor-Dome ice core (a) with the global nitrogen removal (NR)-forcing index (b). The global NR-forcing index was calculated by adding the individual normalized OMZ-NR contribution. The $\mathrm{N}$ isotopic normalization was done by subtracting from each $\delta^{15} \mathrm{~N}$ record its mean and dividing them by its standard deviation. The oceanic $\mathrm{NO}_{3}^{-}$response to the NR forcing can be estimated as the negative of the 3000 year moving average (solid black line). 
is the case for an open ocean site with continuous diffusion/ advection of $\mathrm{NO}_{3}^{-}$, like in all OMZs [Sigman and Casciotti, 2001]. The second one is probably valid because the isotope effects of NR in the different OMZs are similar [Brandes et al., 1998; Liu et al., 1987; Voss et al., 2001].

[40] Our normalized NR-forcing index (Figure 9) shows a remarkable resemblance to the late Quaternary history of atmospheric $\mathrm{CO}_{2}$. With the inclusion of the $\mathrm{SH}$ contribution, our index matches the millennial-scale evolution of the atmospheric $\mathrm{CO}_{2}$ during the late Quaternary in greater detail than through the comparison of the AS history alone [Altabet et al., 2002]. For example, between 40-60 ka B. P., apart from the presence of the three millennial-scale incursions, the clear decreasing trend that is present in the $\mathrm{CO}_{2}$ record is now fully featured in the NR forcing. Moreover, the deglacial $\mathrm{CO}_{2}$ rise is matched both in timing and intensity by the NR forcing once the $\mathrm{SH}$ is considered.

[41] The general consistency of both curves indicates a close coupling between the oceanic $\mathrm{N}$ cycle and atmospheric $\mathrm{CO}_{2}$, despite recent evidence that suggests glacialinterglacial difference in NR has a minor impact upon the global $\mathrm{NO}_{3}^{-}$budget and primary production [Deutsch et al., 2004; Gruber, 2004]. We propose that in addition to the modulation of global oceanic $\mathrm{NO}_{3}^{-}$there is an alternative link between the NR and atmospheric $\mathrm{CO}_{2}$, the physical pump. Low NR rates during the cold stadial periods of the Quaternary imply a better-ventilated thermocline in the ocean regions where the modern OMZs lie. The opposite occurs during various warm interstadials, where poor thermocline ventilation is observed. The augmented or diminished physical ventilation rates of the intermediate water masses, particularly the less-considered midlatitude intermediate water masses like the ESPIW, could play an important role in modulating the millennial-scale $\mathrm{CO}_{2}$ sequestration by the ocean. Colder water, a deeper penetration and enhanced formation rates and volumes would favor more $\mathrm{CO}_{2}$ sequestration by the ocean during low NR-stadial periods and vice versa. Our hypothesis is suitable to be tested in the near future by means of new paleoceanographic studies. However, we would like to point, that regardless of whether the link between NR and atmospheric $\mathrm{CO}_{2}$ be governed by biological or physical processes, the agreement between the normalized isotopic data and the $\mathrm{CO}_{2}$ concentrations during the last $\sim 65 \mathrm{ka} \mathrm{B}$. P. is strong evidence of a tight connection between the $\mathrm{N}$ and $\mathrm{C}$ cycles during the late Quaternary at multiple timescales.

\section{Summary and Conclusions}

[42] High-resolution nitrogen isotope data from the Chilean continental margin during the last ice age show that the intensity of the OMZ in the ESP varied significantly at millennial timescales, with an intrinsic $\mathrm{SH}$ rhythm, and with no signs of an ENSO-like or Dansgaard/Oeschger type of forcing coming from the Equatorial Pacific. The reorganizations of the $\mathrm{OMZ}$ ecosystem were most probably caused by an extratropical process: variation in the thermocline ventilation in the midlatitude formation area of the ESPIW. Moreover, a link between NR and local primary production is not supported by our data. Millennial-scale changes in the size of the Patagonian ice sheet brought time dependant alterations in the fresh water supply from the continent to the adjacent ocean, which were faithfully recorded by the sedimentary $\mathrm{Fe}$ content records and salinity changes off southern Chile. Such fresh water pulses probably added enough buoyancy in the outcropping region of the density surfaces that bound the $\mathrm{OMZ}$ vertical distribution today, that it impeded the subduction of subantarctic waters and the ventilation of the subsurface ESP, promoting the existence of an OMZ and leaving a measurable sedimentary record of NR. On this basis, we can conclude that the OMZ in the ESP experienced an intrinsic SH timing with no evident connection with $\mathrm{NH}$ rapid climate changes. When the $\mathrm{SH}$ contribution to the NR forcing on atmospheric $\mathrm{CO}_{2}$ is included, it results in a global forcing that matches almost every millennial-scale feature of the $\mathrm{CO}_{2}$ evolution during the last $70 \mathrm{ka}$. On this basis, oceanic NR occurring in the world's OMZs is a key component of the marine feedback to climate forcing not only at orbital [Liu et al., 2005], but also at multiple timescales.

[43] Acknowledgments. We gratefully acknowledge Mea Cook, Laura Farías, Carina Lange, and Práxedes Muñoz for comments and help. This work was funded by the Chilean National Commission for Scientific and Technological Research (CONICYT) through the FONDAP Program and by the Fundación Andes. Additional support was provided by the German Ministry for Science and Education through the PUCK project. R.D.P.H. was supported by graduate fellowships coming from Fundación Andes, CONICYT, and MECESUP/UCO2002. This work improved considerably thanks to the comments of two anonymous reviewers.

\section{References}

Agnihotri, R., M. A. Altabet, and T. D. Herbert (2006), Influence of marine denitrification on atmospheric $\mathrm{N}_{2} \mathrm{O}$ variability during the Holocene, Geophys. Res. Lett., 33, L13704, doi:10.1029/2006GL025864.

Altabet, M. A., and R. Francois (1994), Sedimentary nitrogen isotopic ratio as a recorder for surface ocean nitrate utilization, Global Biogeochem. Cycles, 8, 103-116.

Altabet, M. A., R. Francois, D. W. Murray, and W. L. Prell (1995), Climate variations in denitrification in the Arabian Sea from sediment ${ }^{15} \mathrm{~N} /{ }^{14} \mathrm{~N}$ ratios, Nature, 373 , 506-509.

Altabet, M. A., et al. (1999), The nitrogen isotope biogeochemistry of sinking particles from the margin of the eastern North Pacific, Deep Sea Res., Part II, 46, 655-679.
Altabet, M. A., M. J. Higginson, and D. W. Murray (2002), The effect of millennial-scale changes in Arabian Sea denitrification on atmospheric $\mathrm{CO}_{2}$, Nature, 415, 159-162.

Behl, R. J., and J. P. Kennett (1996), Brief interstadial events in the Santa Barbara Basin, NEPacific during the past $60 \mathrm{kyr}$, Nature, 379, 243-246.

Blunier, T., and E. Brook (2001), Timing of millennial-scale climate change in Antarctica and Greenland during the last glacial period, Science, 291, 109-112.

Bostock, H. C., B. N. Opdyke, M. K. Gagan, and L. K. Fifield (2004), Carbon isotope evidence for changes in Antarctic intermediate water circulation and ocean ventilation in the southwest Pacific during the last deglaciation, Paleoceanography, 19, PA4013, doi:10.1029/ 2004PA001047.
Brandes, J. A., and A. H. Devol (2002), A global marine-fixed nitrogen isotopic budget: Implications for Holocene nitrogen cycling, Global Biogeochem. Cycles, 16(4), 1120, doi:10.1029/2001GB001856.

Brandes, J. A., A. H. Devoll, T. Yoshinari, D. A Jayakumar, and S. W. A. Naqvi (1998), Isotopic composition of nitrate in the central Arabian Sea and eastern tropical North Pacific: A tracer for mixing and nitrogen cycles, Limnol. Oceanogr., 43, 1680-1689.

Cannariato, K. G., and J. P. Kennett (1999), Climatically related millennial-scale fluctuations in strength of California margin oxygen-minimum zone during the past $60 \mathrm{k}$. y., Geology, 27, 975-978.

Capone, D. G., J. P. Zehr, H. W. Pearl, B. Bergman, and E. J. Carpenter (1997), Trichodesmiun, a 
globally significant marine cyanobacterium, Science, 276, 1221-1229.

Castro, C. G., F. P. Chavez, and C. A. Collins (2001), Role of the California undercurrent in the export of denitrified waters from the eastern tropical North Pacific, Global Biogeochem. Cycles, 15, 819-830.

Charles, C. D., J. Lynch-Stieglitz, U. S. Ninnemann, and R. G. Fairbanks (1996), Climate connections between the hemisphere revealed by deep sea sediment core ice core correlations, Earth Planet. Sci. Lett., 142, 19-27.

Clement, A. C., R. Seager, and M. A. Cane (2000), Suppression of El Niño during the mid-Holocene by changes in the Earth's orbit, Paleoceanography, 15, 731-737.

Cline, J. D., and I. R. Kaplan (1975), Isotopic fractionation of dissolved nitrate during denitrification in the eastern tropical North Pacific Ocean, Mar. Chem., 3, 271-299.

Codispoti, L. A. (1995), Biogeochemical cycles-Is the ocean losing nitrate, Nature 376, 724

Codispoti, L. A., and J. P. Christensen (1985), Nitrification, denitrification and nitrous oxide cycling in the eastern tropical South Pacific Ocean, Mar. Chem., 16, 277-300.

Codispoti, L. A., et al. (1986), High nitrite levels off northern Peru: A signal of instability in the marine denitrification rate, Science, 233 $1200-1202$

Codispoti, L. A., G. E. Friederich, T. T. Packard, and R. T. Barber (1988), Remotely driven thermocline oscillations and denitrification in the eastern South-Pacific - The potential for high denitrification rates during weak coastal upwelling, Sci. Total Environ., 75, 301-318.

Codispoti, L. A., et al. (2001), The oceanic fixed nitrogen and nitrous oxide budgets: Moving targets as we enter the anthropocene?, $S c i$. Mar., 65, 85-105.

Conkright, M. E., et al. (2002), World Ocean Atlas 2001: Objective Analyses, Data Statistics, and Figures, U. S. Dep. of Comm., Washington, D. C.

Dávila, P. M., D. Figueroa, and E. Muller (2002), Freshwater input into the coastal ocean and its relation with the salinity distribution off austral Chile $\left(35^{\circ}-55^{\circ} \mathrm{S}\right)$, Cont Shelf Res., 22, 521-534.

De Pol-Holz, R., O. Ulloa, L. Dezileau, J. Kaiser, F. Lamy, and D. Hebbeln (2006), Melting of the Patagonian Ice Sheet and deglacial perturbations of the nitrogen cycle in the eastern South Pacific, Geophys. Res. Lett., 33, L04704, doi:10.1029/2005GL024477.

Deutsch, C., D. M. Sigman, R. C. Thunell, A. N. Meckler, and G. H. Haug (2004), Isotopic constraints on glacial/interglacial changes in the oceanic nitrogen budget, Global Biogeochem. Cycles, 18, GB4012, doi:10.1029/ 2003GB002189.

Dezileau, L., O. Ulloa, D. Hebbeln, F. Lamy, J. L. Reyss, and M. Fontugne (2004), Iron control of past productivity in the coastal upwelling system off the Atacama Desert, Chile, Paleoceanography, 19, PA3012, doi:10.1029/2004PA001006.

Emmer, E., and R. C. Thunell (2000), Nitrogen isotope variations in Santa Barbara Basin sediments: Implications for denitrification in the eastern tropical North Pacific during the las 50,000 years, Paleoceanography, 15, 377-387.

EPICA Community Members (2004), Eight glacial cycles from an Antarctic ice core, Nature, 429, 623-628.

Falkowski, P. (1997), Evolution of the nitrogen cycle and its influence on the biologi- cal sequestration of $\mathrm{CO}_{2}$ in the ocean, Nature, 387, 272-275.

Farrell, J. W., T. F. Pedersen, S. E. Calvert, and B. Nielsen (1995), Glacial-interglacial changes in nutrient utilization in the equatorial Pacific Ocean, Nature, 377, 514-517.

Fontugne, M. R., and J. C. Duplessy (1981), Organic carbon isotopes fractionation by marine plankton in the temperature range -1 to $31^{\circ} \mathrm{C}$, Oceanol. Acta, 4, 85-90.

Francois, R., et al. (1997), Contribution of Southern Ocean surface-water stratification to low atmospheric $\mathrm{CO}_{2}$ concentrations during the last glacial period, Nature, 389, 929-935.

Francois, R., M. Frank, M. M. Rutgers van der Loeff, and M. P. Bacon (2004), ${ }^{230} \mathrm{Th}$ normalization: An essential tool for interpreting sedimentary fluxes during the late Quaternary, Paleoceanography, 19, PA1018, doi:10.1029/ 2003PA000939.

Freudenthal, T., T. Wagner, F. Wenzhöfer, M. Zabel, and G. Wefer (2001), Early diagenesis of organic matter from sediments of the eastern and subtropical Atlantic: Evidence from stable nitrogen isotopes and carbon isotopes, Geochim. Cosmochim. Acta, 65, 1795-1808.

Ganeshram, R. S., T. F. Pedersen, S. E. Calvert, and J. W. Murray (1995), Large changes in oceanic nutrient inventories from glacial to interglacial periods, Nature, 376, 755-758.

Ganeshram, R. S., T. F. Pedersen, S. E. Calvert, G. W. McNeill, and M. R. Fontugne (2000), Glacial-interglacial variability in denitrification in the world's oceans: Causes and consequences, Paleoceanography, 15, 361-376.

Gruber, N. (2004), The dynamics of the marine nitrogen cycle and its influence on atmospheric $\mathrm{CO}_{2}$, in The Ocean Carbon Cycle and Climate: Proceedings of the NATO ASI on Ocean Carbon Cycle and Climate, Ankara, Turkey, From 5 to 16 August 2002, NATO Sci. Ser. IV, edited by M. Follows, T. Oguz, pp. 97-148, NATO ASI Ser. Springer, New York.

Haake, B., et al. (2005), Stable nitrogen isotopic ratios of sinking particles and sediments from the northern Indian Ocean, Mar. Chem., 96, $243-255$.

Hebbeln, D., M. Marchant, T. Freudenthal, and G. Wefer (2000), Surface sediment distribution along the Chilean continental slope related to upwelling and productivity, Mar Geol., 164, 119-137.

Hebbeln, D., and Cruise Participants (2001), PUCK, report and preliminary results of R/V Sonne cruise 156, Valparaiso (Chile)-Talcahuano (Chile), March 29-May 14, 2001, Ver. Fachbereich Geowissenschaf. Univ. Bremen 182, 195 pp., Univ. Bremen, Bremen.

Hendy, I. L., T. F. Pedersen, J. P. Kennett, and R. Tada (2004), Intermittent existence of a southern Californian upwelling cell during submillennial climate change of the last 60 kyr, Paleoceanography, 19, PA3007, doi:10.1029/2003PA000965

Higginson, M. J., and M. A. Altabet (2004), Initial test of the silicic acid leakage hypothesis using sedimentary biomarkers, Geophys. Res. Lett., 31, L18303, doi:10.1029/ 2004GL020511.

Holmes, M. E., R. R. Schneider, P. J. Müller, M. Segl, and G. Wefer (1997), Reconstruction of past nutrient utilization in the eastern Angola Basin based on sedimentary ${ }^{15} \mathrm{~N} /{ }^{14} \mathrm{~N}$ ratios, Paleoceanography, 12, 604-614.

Hormazábal, S., G. Shaffer, J. Letelier, and O. Ulloa (2001), Local and remote forcing of sea surface temperature in the coastal upwelling system off Chile, J. Geophys. Res., 106, 16,657-16,671.

Hulton, N. R. J., R. S. Purves, R. D. McCulloch, D. E. Sugden, and M. J. Bentley (2002), The Last Glacial Maximum and deglaciation in southern South America, Quat. Sci. Rev., 21, 233-241.

Indermühle, A., et al. (1999), Holocene carboncycle dynamics based on $\mathrm{CO}_{2}$ trapped in ice at Taylor Dome, Antarctica, Nature, 398, 121 126.

Indermühle, A., E. Monnin, B. Stauffer, T. F. Stocker, and M. Wahlen (2000), Atmospheric $\mathrm{CO}_{2}$ concentration from 60 to $20 \mathrm{kyr} \mathrm{BP}$ from the Taylor Dome ice core, Antarctica, Geophys. Res. Lett., 27, 735-738.

Kaiser, J., F. Lamy, and D. Hebbeln (2005), A 70-kyr sea surface temperature record off southern Chile (Ocean Drilling Program Site 1233), Paleoceanography, 20, PA4009, doi:10.1029/2005PA001146.

Karstensen, J. (2004), Formation of the South Pacific shallow salinity minimum: A Southern Ocean pathway to the tropical Pacific, J. Phys. Oceanogr., 34, 2398-2412.

Karstensen, J., and M. Tomczak (1997), Ventilation processes and water mass ages in the thermocline of the southeast Indian Ocean, Geophys. Res. Lett., 24, 2777-2780.

Kienast, S. S., S. E. Calvert, and T. F. Pedersen (2002), Nitrogen isotope and productivity variations along the northeast Pacific margin over the last 120 kyr: Surface and subsurface paleoceanography, Paleoceanography, 17(4), 1055, doi:10.1029/2001PA000650.

Koutavas, A., J. Lynch-Stieglitz, T. M. Marchitto, and J. P. Sachs (2002), El Niño-like pattern in ice age tropical Pacific sea surface temperature, Science, 297, 226-230.

Lamy, F., D. Hebbeln, and G. Wefer (1998a), Late Quaternary precessional cycles of terrigenous sediment input off the Norte Chico, Chile $\left(27.5^{\circ} \mathrm{S}\right)$ and palaeoclimatic implications, Palaeogeogr. Palaeoclimatol. Palaeoecol., 141, 233-251.

Lamy, F., D. Hebbeln, and G. Wefer (1998b), Terrigenous sediment supply along the Chilean continental margin: Modern regional patterns of texture and composition, Geol. Rundsch., 87, 477-494.

Lamy, F., J. Kaiser, U. Ninnemann, D. Hebbeln, H. W. Arz, and J. Stoner (2004), Antarctic timing of surface water changes off Chile and Patagonian ice sheet response, Science, 304, 1959-1962.

Lehmann, M. F., S. M. Bernasconi, A. Barbieri, and J. A. McKenzie (2002), Preservation of organic matter and alteration of its carbon and nitrogen isotope composition during simulated and in situ early sedimentary diagenesis, Geochim. Cosmochim. Acta, $66,3573-3584$

Liu, K. K. (1979), Geochemistry of inorganic nitrogen compounds in two marine environments: The Santa Barbara Basin and the ocean off of Peru, Ph.D. thesis, Univ. of Calif., Los Angeles.

Liu, K. K., and I. R. Kaplan (1989), The eastern tropical Pacific as a source of ${ }^{15} \mathrm{~N}$-enriched nitrate in seawater off southern California Limnol. Oceanogr., 34, 820-830.

Liu, K. K., P.-T. Shawn, and I. R. Kaplan (1987), Modeling of nitrogen isotopic variation of nitrate within the denitrifying zone in the eastern tropical South Pacific, Eos Trans. $A G U, 68,1714$

Liu, Z., M. A. Altabet, and T. D. Herbert (2005), Glacial-interglacial modulation of eastern tro- 
pical North Pacific denitrification over the last 1.8-Myr, Geophys. Res. Lett., 32, L23607, doi:10.1029/2005GL024439.

Martinez, P., F. Lamy, R. R. Robinson, L. Pichevin, and I. Billy (2006), A typical $\delta^{15} \mathrm{~N}$ variations at the southern boundary of the East Pacific oxygen minimum zone over the last $50 \mathrm{ka}$, Quat. Sci. Rev., 25, $3017-3028$.

Martinson, D., N. G. Pisias, J. D. Hays, J. Imbrie, T. C. J. Moore, and N. J. Shackleton (1987), Age dating and orbital theory of the ice ages: Development of a high-resolution 0 to 300,000 year chronostratigraphy, Quat. Res., 27, 1-27.

McCartney, M. S. (1977), Subantarctic mode water, in A Voyage of Discovery: George Deacon 70th Anniversary Volume, edited by M. V. Angel, pp. 103-119, Elsevier, New York.

McElroy, M. B. (1983), Marine biological controls on atmospheric $\mathrm{CO}_{2}$ and climate, Nature, $302,328-329$.

Mohtadi, M., and D. Hebbeln (2004), Mechanisms and variations of the paleoproductivity off northern Chile $\left(24^{\circ} \mathrm{S}-33^{\circ} \mathrm{S}\right)$ during the past 40,000 years, Paleoceanography, 19, PA2023, doi:10.1029/2004PA001003.

Molinelli, E. J. (1981), The Antarctic influence on Antarctic intermediate water, J. Mar. Res., 39, 267-292.

Morales, C. E., S. Hormazabal, and J. L. Blanco (1999), Interannual variability in the mesoscale distribution of the depth of the upper boundary of the oxygen minimum layer off northern Chile $\left(18^{\circ}-24^{\circ} \mathrm{S}\right)$ : Implications for the pelagic system and biogeochemical cycling, J. Mar. Res., 57, 909-932.

Moreno, P. I., G. L. Jacobson, T. V. Lowell, and G. H. Denton (2001), Interhemispheric climate links revealed from a late-glacial coo episode in southern Chile, Nature, 409, 804-808.

Mudelsee, M. (2002), TAUEST: A computer program for estimating persistence in unevenly spaced weather/climate time series, Comput. Geosci., 28, 69-72.

Müller, P. J. (1977), C/N ratios in the Pacific deep sea sediments: Effect of inorganic ammonium and organic nitrogen-compounds sorbed by clays, Geochim. Cosmochim. Acta, $41,765-776$

Muñoz, P., et al. (2004), Recent sediment and mass accumulation rates based on ${ }^{210} \mathrm{~Pb}$ along the Peru-Chile continental margin, Deep Sed Res., Part II, 51, 2523-2541.

Pahnke, K., and R. Zahn (2005), Southern Hemisphere water mass conversion linked with North Atlantic climate variability, Science, 307, 1741-1746.

Pahnke, K., R. Zahn, H. Elderfield, and M. Schulz (2003), 340,000-yea centennial-scale marine record of Southern Hemisphere climatic oscillation, Science, $301,948-952$.
Peters, K. E., R. E. Sweeney, and I. R. Kaplan (1978), Correlation of carbon and nitrogen stable isotope ratios in sedimentary organic matter, Limnol. Oceanogr., 23, 598-604.

Rau, G. H., T. Takahashi, and M. D. J. D. (1989), Latitudinal variations in plankton ${ }^{13} \mathrm{C}$ : Implications for $\mathrm{CO}_{2}$ and productivity of past oceans, Nature, 341, 516-518.

Robinson, R. S., A. Mix, and P. Martinez (2007), Southern Ocean control on the extent of denitrification in the southeast Pacific over the last $70 \mathrm{ka}$, Quat. Sci. Rev., $26,201-212$

Schneider, W., R. Fuenzalida, E. RodríguezRubio, J. Garcés-Vargas, and L. Bravo (2003), Characteristics and formation of eastern South Pacific intermediate water, Geophys. Res. Lett., 30(11), 1581 , doi:10.1029/2003GL017086.

Schubert, C. J., and S. E. Calvert (2001), Nitrogen and carbon isotopic composition of marine and terrestrial organic matter in Arctic Ocean sediments: Implications for nutrient utilization and organic matter composition, Deep Sea Res., Part I, 48, 789-810.

Schulz, M., and M. Mudelsee (2002), REDFIT: Estimating red-noise spectra directly from unevenly spaced paleoclimate time series, Comput. Geosci., 28, 421-426.

Sigman, D. M., and K. L. Casciotti (2001), Nitrogen isotopes in the ocean, in Encyclopedia of Ocean Sciences, edited by J. H Steele, K. K. Turekian, and S. A. Thorpe, pp. 1884-1894, Elsevier, New York.

Sigman, D. M., M. A. Altabet, R. Michener, D. C. McCorkle, B. Fry, and R. M. Holmes (1997), Natural abundance-level measurement of the nitrogen isotopic composition of oceanic nitrate: An adaptation of the ammonia diffusion method, Mar. Chem., 57, $227-242$

Sigman, D. M., M. A. Altabet, D. C. McCorkle, R. Francois, and G. Fischer (1999), The $\delta^{15} \mathrm{~N}$ of nitrate in the Southern Ocean: Consumption of nitrate in surface waters, Global Biogeochem. Cycles, 13, 1149-1166.

Smith, H. J., H. Fischer, D. Mastroianni, B. Deck, and M. Wahlen (1999), Dual modes of the carbon cycle since the Last Glacial Maximum, Nature, 400, 248-250.

Spero, H. J., and D. W. Lea (2002), The cause of carbon isotope minimum events on glacial terminations, Science, 296, 522-525.

Stocker, T. F. (1998), The seesaw effect, Science, $282,61-62$

Stott, L., C. Poulsen, S. Lund, and R. Thunell (2002), Super ENSO and global climate oscillations at millennial time scales, Science, 297, $222-226$.

Suthhof, A., V. Ittekkot, and B. Gaye-Haake (2001), Millennial-scale oscillation of denitrification intensity in the Arabian Sea during the late Quaternary and its potential influence on atmospheric $\mathrm{N}_{2} \mathrm{O}$ and global climate, Global Biogeochem. Cycles, 15, 637-649.
Sweeney, R. E., and I. R. Kaplan (1980), Natural abundances of ${ }^{15} \mathrm{~N}$ as a source indicator for near-shore marine sedimentary and dissolved nitrogen, Mar. Chem., 9, 81-94.

Thomson, D. J. (1990), Time series analysis of Holocene climate data, Philos. Trans. R. Soc. London, Ser. A, 330, 601-616.

Thunell, R. C., and A. B. Kepple (2004), Glacial-Holocene $\delta^{15} \mathrm{~N}$ record from the Gulf of Tehuantepec, Mexico: Implications for denitrification in the eastern equatorial Pacific and changes in atmospheric $\mathrm{N}_{2} \mathrm{O}$, Global Biogeochem. Cycles, 18, GB1001, doi:10.1029/ 2002GB002028.

Toggweiler, J. R., K. Dixon, and W. S. Broecker (1991), The Peru upwelling and the ventilation of the South Pacific thermocline, J. Geophys. Res., 96, 20,467-20,497.

Tsuchiya, M., and T. D. Talley (1998), A Pacific hydrographic section at $88^{\circ} \mathrm{W}$ : Water property distribution, J. Geophys. Res., 103, 12,89912,918

Turney, C., A. Kershaw, S. Clemens, N. Branch, P. Moss, and L. Fifield (2004), Millennial and orbital variations of El Nino/Southern Oscillation and high-latitude climate in the last glacial period, Nature, 428, 306-310.

Tyrrell, T. (1999), The relative influences of nitrogen and phosphorus on oceanic primary production, Nature, 400, 525-531.

Ulloa, O., R. Escribano, S. Hormazabal, R. A. Quinones, R. R. González, and M. Ramos (2001), Evolution and biological effects of the 1997-98 El Niño in the upwelling ecosystem off northern Chile, Geophys. Res. Lett., $28,1591-1594$

Voss, M., J. W. Dippner, and J. P. Montoya (2001), Nitrogen isotope patterns in the oxygen-deficient waters of the eastern tropical North Pacific Ocean, Deep Sea Res., Part I, 48, 1905-1921

Wooster, W. S., and M. Gilmartin (1961), The Peru-Chile undercurrent, J. Mar. Res., 19, 97 122.

R. De Pol-Holz, M.S. 8, Woods Hole Oceanographic Institution, Woods Hole, MA 02543, USA. (rdepolholz@whoi.edu)

L. Dezileau and P. Sabatier, Géosciences Montpellier, Université Montpellier 2, Place Eugene Bataillon, F-34095 Montpellier Cedex 05, France. (dezileau@dstu.univ-montp2.fr)

D. Hebbeln, Fachbereich Geowissenschaften, Universität Bremen, Postfach 330440, D-28334 Bremen, Germany. (dhebbeln@uni-bremen.de)

F. Lamy, Alfred Wegener Institute, Am Handelshafen 12, D-27570 Bremerhaven, Germany. (frank.lamy@awi.de)

O. Ulloa, Departamento de Oceanografía, Universidad de Concepción, Casilla 160-C, Correo 3, Concepción, Chile. (oulloa@profc. udec.cl) 